OECD Education Policy Perspectives No. 11

\title{
EDUCATION POLICY OUTLOOK IN THE CZECH REPUBLIC
}

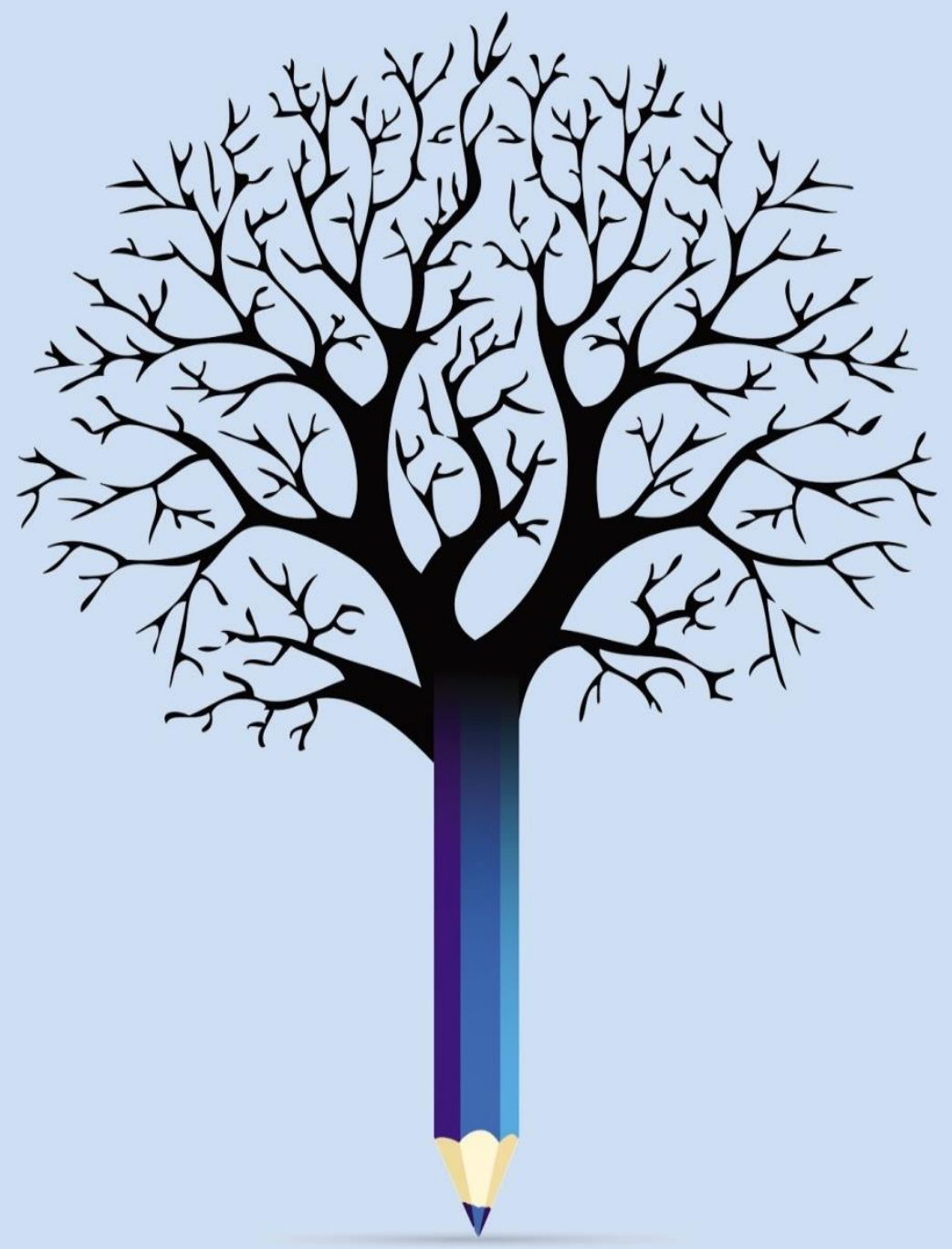




\section{EDUCATION POLICY OUTLOOK}

This policy profile on education in the Czech Republic is part of the Education Policy Outlook series, which presents comparative analysis of education policies and reforms across OECD countries. Building on the OECD's substantial comparative and sectoral policy knowledge base, the series offers a comparative outlook on education policy. This country policy profile is an update of the first policy profile of the Czech Republic (2013) and provides: analysis of the educational context, strengths, challenges and policies; analysis of international trends; and insight into policies and reforms on selected topics. It is an opportunity to take stock of progress and where the education system stands today from the perspective of the OECD through synthetic, evidence-based and comparable analysis.

In addition to country-specific profiles, the series also includes a recurring publication. The first volume, Education Policy Outlook 2015: Making Reforms Happen, was released in 2015. The second volume, Education Policy Outlook 2018: Putting Student Learning at the Centre was released in 2018. Its complement, Education Policy Outlook 2019: Working Together to Help Students Achieve their Potential was released in autumn 2019. Designed for policy makers, analysts and practitioners who seek information and analysis of education policy taking into account the importance of national context, the country policy profiles offer constructive analysis of education policy in a comparative format. Each profile reviews the current context and situation of a country's education system and examines its challenges and policy responses, according to six policy levers that support improvement:

Students: How to raise outcomes for all in terms of 1) equity and quality and 2) preparing students for the future;

Institutions: How to raise quality through 3) institutional improvement and 4) evaluation and assessment;

System: How the system is organised to deliver education policy in terms of 5) governance and 6) funding.

Some country policy profiles contain spotlight boxes on selected policy issues. They are meant to draw attention to specific policies that are promising or showing positive results and may be relevant for other countries.

Special thanks to the Government of the Czech Republic and, in particular, the Ministry of Education, Youth and Sports, for its active input during consultations and constructive feedback on this report. We also thank the European Commission for its valuable analytical and financial support for the update of this country policy profile.

Authors: This country policy profile was prepared by Marie Ullmann, Diana Toledo Figueroa and Christa Rawkins in the Policy Advice and Implementation Division, led by Paulo Santiago. Editorial support was provided by Stephen Flynn and Rachel Linden. This profile builds on the knowledge and expertise of many project teams across the OECD's Directorate for Education and Skills, to whom we are grateful. Christele Duvieusart and Ulrike Pisiotis contributed on behalf of the European Commission Directorate-General for Education and Culture.

Sources: Subject to country participation, this country policy profile draws on OECD indicators from the Programme for International Student Assessment (PISA), the Survey of Adult Skills (PIAAC), the Teaching and Learning International Survey (TALIS) and the annual publication Education at a Glance, and refers to country and thematic studies such as OECD work on early childhood education and care, teachers, school leadership, evaluation and assessment for improving school outcomes, equity and quality in education, governing complex education systems, school resources, vocational education and training, and tertiary education. This profile also draws on information in the OECD Education Policy Outlook National Survey for Comparative Policy Analysis completed in 2016 by the Government of the Czech Republic, as well as information provided by the Ministry of Education, Youth and Sports between 2018 and 2020 as part of the Education Policy Outlook's activities with countries.

Most of the figures quoted in the different sections refer to Annex $B$, which presents a table of the main indicators for the sources used throughout the country policy profile. Hyperlinks to the reference publications are included throughout the text for ease of reading, and also in the References and further reading section, which lists both OECD and non-OECD sources.

More information is available from the OECD Directorate for Education and Skills (www.oecd.org/edu) and its web pages on the Education Policy Outlook (www.oecd.org/edu/policyoutlook.htm).

In the context of the coronavirus (COVID-19) pandemic, some information is provided about initial responses. 


\section{2 | No. 11 - EDUCATION POLICY OUTLOOK IN THE CZECH REPUBLIC}

\section{TABLE OF CONTENTS}

Highlights..

Equity and quality

Growing ECEC enrolment, but inequities have persisted across the sytem

Preparing students for the future

High educational attainment and adult skills, with transitions to be strengthened.

School improvement

Efforts have been undertaken to improve working conditions for teachers

Evaluation and assessment

Efforts to establish and further develop consistent mechanisms and frameworks

Governance

Balancing education policy in a fragmented system

Funding

Low levels of education expenditure, with changes to allocation mechanisms

Annex A: Structure of the Czech Republic's education system

Annex B: Statistics

References and further reading

Notes

Figures

Figure 1. Trends and comparative performance of 15 -year-olds in reading, PISA .5

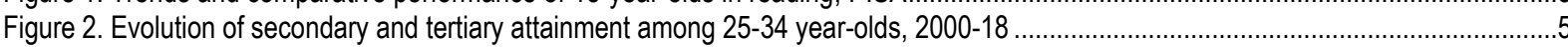

Figure 3. Selected equity and quality indicators for the Czech Republic, PISA 2018 ....................................................................10

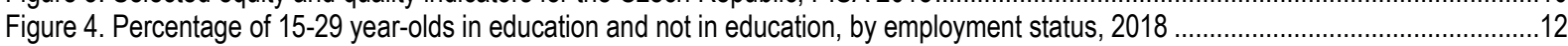

Figure 5. The learning environment according to students, PISA 2018 ......................................................................................14

Figure 6. Percentage of students in schools where the principal reported assessments of students, PISA $2015 \ldots \ldots \ldots \ldots \ldots \ldots \ldots \ldots \ldots \ldots \ldots \ldots . . .16$

Figure 7. Percentage of decisions taken at each level of government for public lower secondary schools (2017)..................................18

Figure 8. Annual expenditure per student (2016) and recent trends, by level of education ...............................................................21

\section{Spotlights}

Spotlight 1. The Czech education system's initial response to the COVID-19 pandemic.................................................................

Spotlight 2. Key policies, key challenges and previous OECD recommendations for the Czech Republic ................................................6

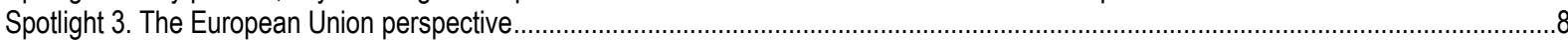

Spotlight 4. Strategy for Education Policy of the Czech Republic until 2020 (2014) ..................................................................19

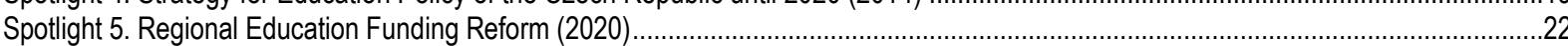




\section{3 | No. 11 - EDUCATION POLICY OUTLOOK IN THE CZECH REPUBLIC}

\section{HIGHLIGHTS}

Note: Most of the content in this profile was written before the COVID-19 outbreak. As such, it offers insight into pre-existing conditions that may influence the system's responsiveness in the context of the crisis and help inform longer-term efforts to strengthen resilience. Spotlight 1 summarises the Czech Republic's initial responses to the crisis. Its structure is based on work by the Education Policy Outlook in 2020 to support countries in these efforts.

\section{The Czech Republic's educational context}

Students: Among 15-year-olds, in PISA 2018, the Czech Republic's performance in reading was similar to the OECD average ${ }^{1}$, and mathematics and science performance were above average. Adults in the Czech Republic have comparatively high educational attainment, and scored above average in both literacy and numeracy in the OECD Survey of Adult Skills (PIAAC) 2012. Progress has been made in enrolment rates in early childhood education and care (ECEC) for children aged three and older, although participation remains well below the OECD average for children under the age of three.

Institutions: Teachers in the Czech Republic benefit from high levels of qualification, certification and participation in professional development programmes. Similarly, school leaders have high participation rates in school administration or principal training programmes before or after taking up their position. Teachers' working conditions include class sizes which are around the OECD average, below-average teaching hours but lower-than-average salaries compared to their Czech peers in other professions, although efforts have been made to address this. The Czech Republic has been working to strengthen its evaluation and assessment system, including introducing standardised national examinations, tests and sampled assessments to provide system-level data on student learning outcomes. External school evaluations remain the principal accountability mechanism within the system.

System: The Czech education system is highly decentralised; in 2017, schools had the second-largest share of responsibility for educational decisions at lower secondary level among OECD countries. Central government steers the system through key documents, such as the Framework Educational Programme and the Strategy for Education Policy of the Czech Republic until 2020. Both local and regional governance layers are also active in the education system. This adds complexity to funding streams and allocations. Expenditure per student in the Czech Republic was below the OECD average at all education levels in 2016, but an increase in total expenditure and a fall in student numbers led to an increase of per-student spending across primary to tertiary education, from 2010 to 2016.

\section{Key policy issues}

Performance gaps between advantaged and disadvantaged students in the Czech Republic in PISA 2018 remained above average and further inequities are observed for students with Roma backgrounds. Some systemlevel policies that may contribute to this include early tracking into different educational pathways and the provision of reduced curricula in some types of schools. Several vocational education and training pathways are available and these are popular; however, quality and labour market relevance require strengthening to ensure the employability of graduates. The Czech Republic continues to make efforts to raise the attractiveness of the teaching profession and to ensure a high-quality workforce; this could be supported by improving the relationship between teacher performance, appraisal, and salary and career progression. The Czech Republic could also further develop an improvement-focused national education monitoring system, particularly regarding external school evaluation and classroom-based student assessment. There are important regional performance differences which require better monitoring in order to be fully understood. At system level, education governance is fragmented and some municipalities have low capacity or resources, contributing further to inequalities. More equal distribution of finances across regions could ensure greater equity; current policy work aims to address this (see Spotlight 5).

\section{Strengthening adaptability and resilience in the context of COVID-19 (see Spotlight 1)}

Initial evidence suggests that pre-existing resources in the education system facilitated areas of the Czech Republic's early response to the pandemic. The Digital Education Strategy to 2020 (2014) (see "Governance"), which has had a positive impact on students' digital skills, may have helped facilitate distance learning, while different supporting projects or institutions for teachers and school leaders were able to quickly mobilise resources to provide professional development and supportive professional communities. As the Czech Republic works to balance short-term responsiveness with longer-term strategic aims and resilience, the crisis has brought specific challenges. In view of the Czech Republic's ongoing work to make the education system more inclusive and equitable, stronger targeted support from the central government for disadvantaged and Roma students could in turn help stimulate more consistent and ongoing support efforts from local and regional authorities. As education institutions reopen, these students will continue to require extra support. Furthermore, in the reflective discussions following the crisis, there may be an opportunity to enhance collaboration among governance levels by establishing formal channels for mutual reflection and peer learning. 


\section{Spotlight 1. The Czech education system's initial response to the COVID-19 pandemic}

On 11 March 2020, the World Health Organisation declared the COVID-19 coronavirus outbreak a global pandemic. Education systems across the world have felt the force of the crisis as confinement measures triggered widespread closures of education institutions. On 10 March, the Czech Republic announced the closure of all primary, secondary and tertiary institutions, and professional schools from the 11 March. A phased reopening of schools began from 11 May. In light of the work of the Education Policy Outlook in 2020 in the context of this pandemic, this spotlight offers an insight into system readiness and immediate responses across five key areas.

1. Ensuring continued access to learning and smooth educational pathways: School leaders were charged with assigning work to staff, prioritising curricula and selecting appropriate learning and communications tools. In support, the Ministry of Education, Youth and Sports (MŠMT) created a website, centralising advice, guidelines and tools for educators, parents and students from primary to tertiary, and published a set of best practices. Czech Television broadcast daily educational programmes and launched an online bank of educational videos. Regular webinars and blogs to support teachers, and a tech support group on Facebook were established through the National Pedagogical Institute and the System of Professional Development Support for Teachers and Directors project. The MŠMT delayed the Maturita and upper secondary school admissions examinations to at least 21 days and 14 days respectively, after the reopening of schools; various measures, including a YouTube channel and mobile application, were launched to support examination preparation from a distance. Regulatory adjustments enabled universities to adapt the academic year and admissions procedures, and to conduct examinations remotely.

2. Strengthening the internal world of the student: The MŠMT developed a handbook for children, in comic format, informing them about the coronavirus, encouraging responsible behaviour and offering emotional support. On-site school counselling services resumed with the first wave of school reopenings.

3. Providing targeted support and interventions for vulnerable children and families: Schools were asked to provide educational material to students without access to digital education. Schools that offered extra support measures to students with specific needs received funding to cover the cost of such measures. There were also local examples of targeted support: in Prague, missions for locally-recruited volunteers included support for families of children with particularly challenging special educational needs.

4. Harnessing wider support and engagement at local and central level: Although not forced to close, most kindergarten providers chose to do so. Emergency childcare was coordinated at regional level for children of essential workers between 0 and

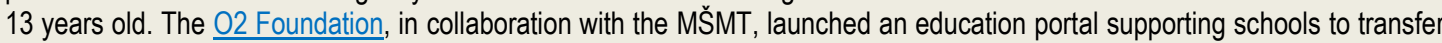
their work online, offered free consultations with experts and awarded grants to schools implementing distance education. At the local level, students were mobilised to support their community: the University of South Bohemia volunteer programme provided babysitting, tutoring and food shopping, and in the Liberec region, students and schools made and distributed protective equipment for local health services.

5. Collecting, disseminating and improving the use of information about students: For the period of closure, the MŠMT did not require teachers to log student absences or pedagogical provision, and class books would not be inspected. Formative and verbal assessment methods were promoted to monitor learning during distance education. The Czech Republic introduced regulations for the evaluation of the second semester: assessment data collected prior to closure would be prioritised, or during closure if the student had adequate conditions to engage in distance education; if necessary, grades from the first semester would be used. The Czech Schools Inspectorate conducted a survey of principals to ascertain forms and methods of distance $\underline{\text { education, reaching nearly } 5000 \text { primary and secondary schools. A survey of parents of students in compulsory education was }}$ carried out by an independent research team.

\begin{tabular}{|c|c|c|c|c|c|}
\hline \multicolumn{2}{|r|}{ Selected indicators of system readiness (OECD) } & $\begin{array}{l}\text { Czech } \\
\text { Republic }\end{array}$ & Average & Min & Max \\
\hline \multicolumn{6}{|c|}{ Students' readiness (according to students' self-reports in PISA 2018) } \\
\hline 1 & Index of self-efficacy & -0.28 & 0.01 & -0.61 & 0.36 \\
\hline 2 & $\begin{array}{l}\text { Percentage of students in disadvantaged schools } w \text { ith access to a } \\
\text { computer at home that they can use for school w ork }\end{array}$ & $88.7 \%$ & $81.5 \%$ & $23.5 \%$ & $96.5 \%$ \\
\hline \multicolumn{6}{|c|}{ Teachers' readiness (according to lower secondary teachers' self-reports in TALIS 2018) } \\
\hline 3 & $\begin{array}{l}\text { Percentage of teachers with a high level of need for professional } \\
\text { development related to ICT skills for teaching }\end{array}$ & $13.0 \%$ & $17.7 \%$ & $5.3 \%$ & $39.0 \%$ \\
\hline 4 & $\begin{array}{l}\text { Percentage of teachers agreeing that most teachers in the school } \\
\text { provide practical support to each other w hen applying new ideas }\end{array}$ & $76.7 \%$ & $77.9 \%$ & $64.7 \%$ & $86.5 \%$ \\
\hline
\end{tabular}

Note: The information presented in this spotlight covers key measures announced or introduced before 07 May 2020. 


\section{KEY TRENDS IN PERFORMANCE AND ATTAINMENT}

In PISA 2018, the Czech Republic performed around the OECD average in reading (490 points) and performance has remained steady across PISA cycles. In the OECD Survey of Adult Skills (PIAAC) 2012, the literacy skills of Czech adults (16-65 year-olds) were higher than on average across the OECD with a mean score of 274 points compared to an average of 268 points.

Figure 1. Trends and comparative performance of 15 -year-olds in reading, PISA
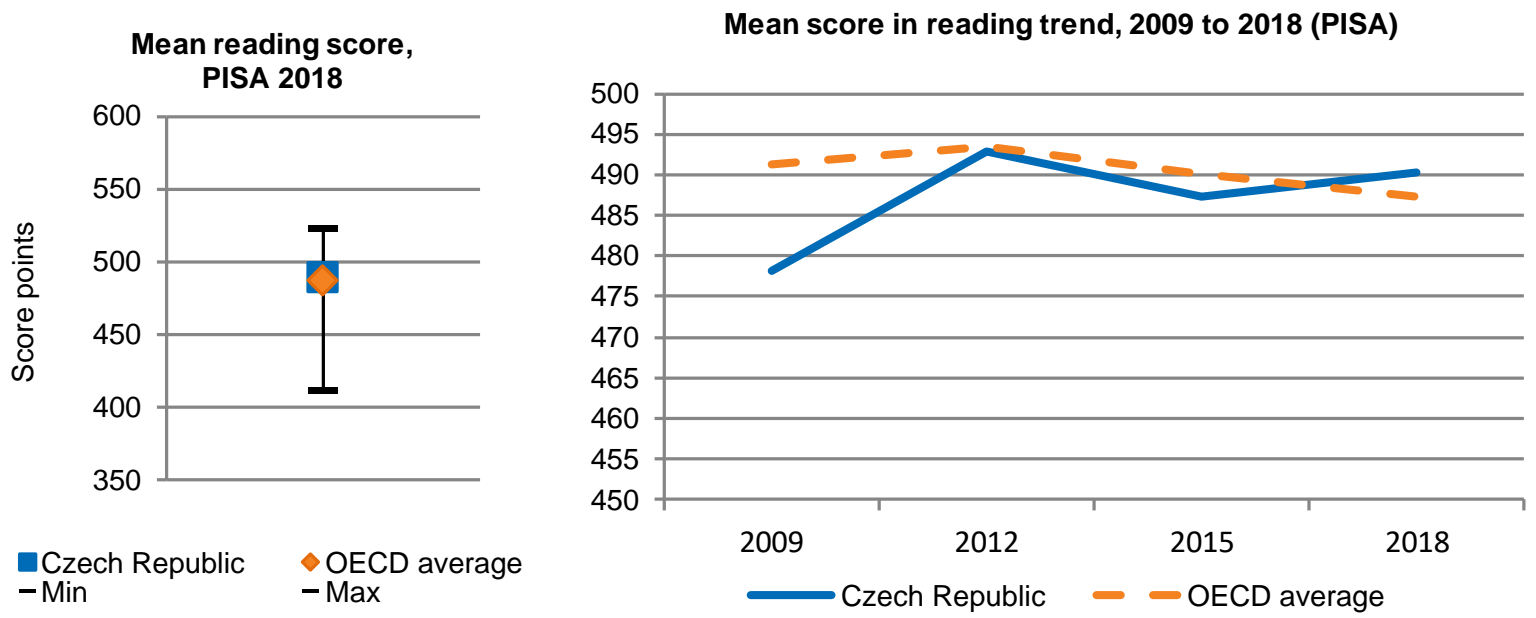

Note: "Min"/"Max" refer to OECD countries with the lowest/highest values.

Source: OECD (2019), PISA 2018 Results (Volume I): What Students Know and Can Do, PISA, OECD Publishing, Paris, https://doi.org/10.1787/5f07c754-en.

Attainment levels at upper secondary level are high in the Czech Republic. The share of population aged 25-34 with at least an upper secondary qualification was among the largest in the OECD, in 2018 (93.7\%, compared to an OECD average of $85.4 \%$ ). Among the same age group, tertiary attainment in the Czech Republic increased from only $18 \%$ in 2008 to $33 \%$ in 2018 . Although it remained below the OECD average of $44 \%$, this marked a 16-point increase since 2008 for the Czech Republic, compared to an average increase of 9 points across the OECD. This increase was more pronounced for women than men: the share of women with tertiary attainment increased by 21 percentage points whereas that of men increased by 10 percentage points, although this is in line with gender trends across OECD countries over the same period.

Figure 2. Evolution of secondary and tertiary attainment among 25-34 year-olds, 2000-18
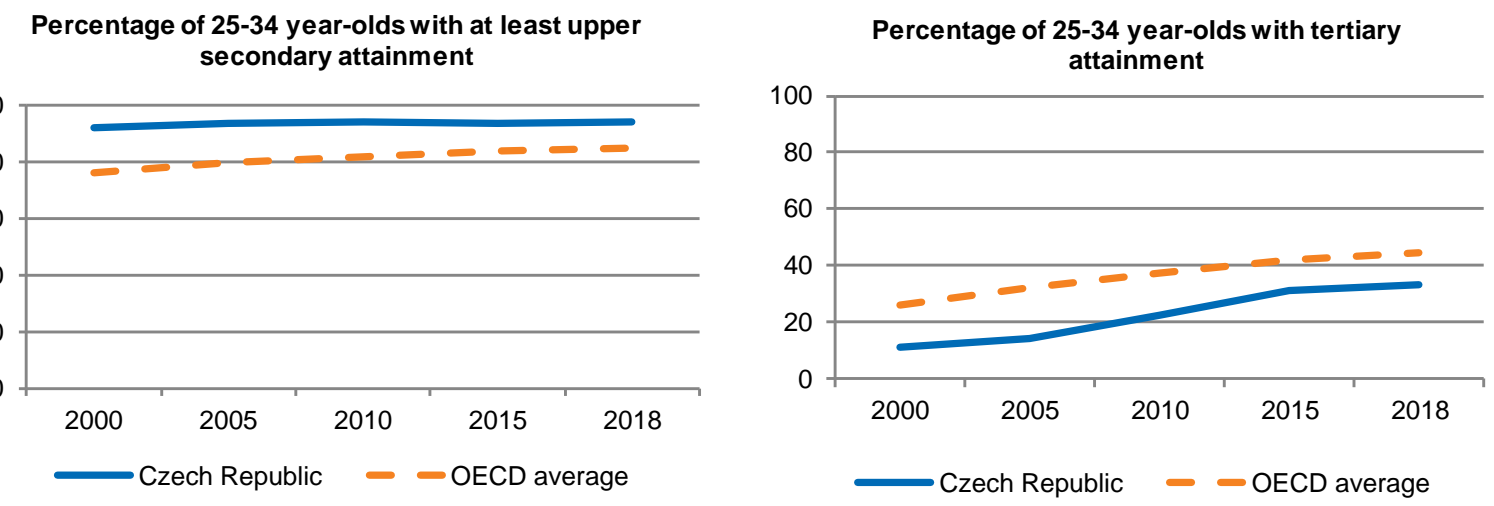

Source: OECD (2019), Education at a Glance 2019: OECD Indicators, OECD Publishing, Paris, https://doi.org/10.1787/f8d7880den. 


\section{Spotlight 2. Key policies, key challenges and previous OECD recommendations for the Czech Republic}

\author{
Main education policies and \\ practices included in this country \\ policy profile
}

\author{
Key challenges identified and \\ recommendations previously \\ provided by the OECD
}

\section{STUDENTS}

- Compulsory pre-primary education for five-year-olds (2017)

- Extension of legal entitlement to pre-primary education for four- and three-year-olds (2017)

- Amendment to the Education Act (2015) on inclusive education

- Amendment to the Decree on Education of Pupils with Special Educational Needs and of Gifted Pupils (2019)

- Inclusive and Quality Education in Territories with Socially Excluded Localities (2016-2022)

- Recommendation on the joint education of Roma and nonRoma (2017)

- Recommendation for a unified approach to establishing collaborative contracts between schools and employers (2015)

- Amendment to the Education Act (2017) on workplace training and collaboration between employers and schools

- The Modernisation of vocational education and training (VET) through Collaboration with the Industry project (2017-2020)

- National Register of Qualifications (2007)

- National System of Occupations (2004)

- Higher Education Act (2016)

- National Accreditation Bureau for Higher Education (2016)
Key challenges identified [2011, 2012, 2014, 2016, 2018]: The OECD has previously identified a need to reduce the influence of social background on student outcomes. The existence of practical schools and early tracking, as well as difficulties for students transferring from one educational track to another, had caused equity challenges, particularly for Roma children. Additionally, the OECD highlighted lower student performance and quality of teaching within the VET sector, and underdeveloped links to the labour market. Furthermore, the OECD reported that VET was less attractive than general education, and experiences a higher dropout rate. Skills mismatches for both under- and over-skilled workers were identified by the OECD and lifelong learning was found to require strengthening. Among women specifically, labour force participation was found to fall with childbirth, contributing to gender inequalities.

Summary of previous related OECD recommendations: The OECD has previously recommended that the Czech Republic work to improve equity by encouraging ECEC enrolment and providing additional support to schools to integrate Roma students and children with mild special education needs. The OECD suggested that female labour market participation be boosted through adequate supply of affordable and high-quality ECEC and job flexibility. Regarding VET, the OECD previously recommended introducing contractual employment relationships between apprentices and employers, and including employers in the design of curricula. This could also help to address skills gaps. Furthermore, the OECD suggested encouraging employers to provide training to under-skilled workers through tax subsidies and facilitating access to secondary and tertiary courses for all ages.

\section{INSTITUTIONS}

- Framework of professional development for pedagogical workers (2017)

- Amendment to Education Act on the appointment and dismissal of school leaders (2015)

- Programme of salary increases for teachers $(2015,2017)$

- Amendment to the Education Act on the rights and obligations of teaching staff (2017)

- Free online portal for teachers (2012)

- Supporting Capacity Building for Basic Literacies in PrePrimary and Basic Education - Supporting Teaching Practice (2016-2021)
Key challenges identified [2012; 2016]: The OECD has previously identified challenges related to teachers' low social status, and a school environment which could be more conducive to encouraging collaboration and discussion among teachers. For school principals, the OECD found that relevant legislation and training focused on the legal and administrative role of principals, leaving pedagogical leadership underdeveloped. Furthermore, the OECD previously reported that appointment, appraisal and remuneration decisions risked politicisation. Finally, the OECD previously reported a lack of policy attention in the area of system evaluation with key information gaps on student performance at national level. Furthermore, the OECD noted that shifting the focus of school evaluation from compliance to improvement would be a challenge. 
- $\quad$ Strategic Management and Planning in Schools and Regions project (2016)

- New unified entrance examination for upper secondary schools (2016)

- New Criteria for the Evaluation of the Conditions, Course and results of Education (2015)

- Complex System of Evaluation project (2017-20)

- National System of Inspection Evaluation of the Educational System (2011-15)

- $\quad$ Standardised school-leaving examination (2011)

- Amendment to the Education Act on unified school-leaving examination for vocational programmes (2015)

- Full-cohort national standardised tests at grades five and nine (2011)

- Long-Term Plans for Education and the Development of the Education System $(2011,2015,2019)$

- Strategy for Education Policy until 2020 (2014)

- Revision of the Framework Education Programme (201722)

- Digital Education Strategy to 2020 (2014)

- Operational Programme Research, Development and Education (2014-20)

- Nursery and Basic School Capacity Development Fund (2014)

- New higher education funding system (2018)

- Programme to promote mutual cooperation between HEls (2017-20)

- Amendment to the Education Act for the regional education funding reform (2017)
Summary of previous related OECD recommendations: Previous OECD recommendations related to teachers include increasing efforts to attract and retain high-calibre teachers through building on teacher salary increases and encouraging collaboration through promoting peer discussion and observation in career structure job descriptions. The OECD also recommended that the Czech Republic create a vision of and support for pedagogical leadership in schools. The OECD suggested improving system evaluation through capacitybuilding across the school system and developing a broader set of informational components. To support policy communication and implementation in this area, the OECD proposed enhancing staff competencies, as well as piloting and evaluating new initiatives. Additionally, the OECD recommended that school principals' evaluation be run by school-organising bodies to reinforce their role as instructional leaders. Finally, the OECD recommended improving consistency in teacher-based assessment and introducing national standardised tests.

\section{SYSTEM}

Key challenges identified [2010, 2011, 2014, 2016]: The OECD has previously identified an overarching need for education reform to promote human capital development. Specific challenges for the ECEC sector include better defining curriculum goals and aligning curricula for continuous child development. The OECD highlighted that regional governance of upper secondary VET required greater transparency and accountability to ensure a match between labour market demand and student choice, and securing national quality standards. In addition, the regional governance of pre-schools and basic schools was seen to create an additional layer of decision making which caused difficulties for equity and financial assessments. The OECD previously found that the education framework required more regular revision to capture changing needs. Furthermore, the OECD noted that the rapid expansion of tertiary education brought relevance and funding challenges.

Summary of previous related OECD recommendations: The OECD has previously recommended that the Czech Republic adopt a broader approach to defining goals and content of ECEC, setting up a framework to support staff in improving classroom quality, a curriculum emphasising equality and respect, and guiding principles based on community and cultural values. The OECD suggested that VET governance could be improved by establishing clearer procedures and more transparent criteria for the development of regional education plans and that these could involve a range of stakeholders. Funding could be improved by increased benchmarking and flexibility in grant spending.

Note: The information on key challenges and recommendations contained in this spotlight draws from a desk-based compilation from previous OECD publications (subject to country participation). The spotlight is intended for exploratory purposes to promote policy dialogue and should not be considered an evaluation of the country's progress on these recommendations. Causality should not be inferred either: while some actions taken by a country could correspond to previous OECD recommendations, the OECD acknowledges the value of internal and other external dynamics to promote change in education systems.

Main sources: 2011, 2014, 2016, 2018: The Economic Survey of the Czech Republic; 2010: Reviews of Vocational Education and Training - Learning for Jobs, Czech Republic; 2012: Quality Matters in Early Childhood and Care, Czech Republic; 2012: OECD Reviews of Evaluation and Assessment in Education: Czech Republic; 2016: OECD Reviews of School Resources: Czech Republic. 


\section{8 | No. 11 - EDUCATION POLICY OUTLOOK IN THE CZECH REPUBLIC}

\section{Spotlight 3. The European Union perspective:}

\section{The Czech Republic's education and training system and the Europe 2020 Strategy}

In the European Union's growth and employment strategy, Europe 2020, education and training is recognised as a key policy area in contributing to Europe's economic growth and social inclusion. The European Union set a two-fold target in education by 2020: reducing the rates of early school leaving below $10 \%$, and reaching at least $40 \%$ of $30-34$ year-olds completing tertiary or equivalent education. Countries set their own related national targets. The Europe 2020 goals are monitored through the European Union's yearly assessment of the main economic and growth issues.

The European Semester Country Report 2020 identified a number of key issues for the Czech Republic in education and training:

- Well below the EU average, the early school leaving rate was markedly higher in certain regions and among disadvantaged groups. At $6.7 \%$ in 2019 , it exceeded the $5.5 \%$ national target for 2020 and showed a particularly high proportion among people with disabilities. The rate for Roma pupils was estimated at $57 \%$ in 2016 .

- The tertiary education attainment rate for $30-34$ year-olds was $35.1 \%$ in 2019 , exceeding the $32 \%$ national target for 2020 . The increase in tertiary education attainment has been among the fastest in the EU over the past decade, in particular for women. The employment rate of recent tertiary education graduates remained high, at $88.2 \%$ in 2019 . However, completion rates were low and so was the share of children (18.9\%) whose parents attained upper secondary or post-secondary non-tertiary education as their highest qualification who achieve tertiary education themselves.

- The government adopted measures to improve the attractiveness of the teaching profession, including increased compulsory practical training for future teachers. Wage increases for teachers in 2019 remained relatively lower than those for other public servants. Combined with limited career prospects, this has impacted the attractiveness of the profession. Shortages of qualified teachers were pronounced, in particular in primary education and for teachers of English, Physics, and Information and Communications Technology.

- In PISA 2018, socio-economic inequalities in educational outcomes had increased over recent years as the gaps between socioeconomic groups and between schools were increasing and were reflected in regional disparities. The percentage of 15-year-old students with a low socio-economic background who underperform in reading is 29.7 percentage points greater than for those with a high socio-economic background. The future Strategy for Education 2030 aimed to develop key competences and reduce inequalities, supporting teachers and school heads and transforming the content and methods of education.

- While being positive overall, the impact of the inclusive education reform on the participation of Roma children in mainstream education has remained limited. The reform is a major concerted effort.

- Participation in early childhood education and care continues to catch up with other Member States.

- The provision of vocational education and training has been improving. A long-term plan for education (2019-2023) to improve the quality of vocational education and training was adopted in June 2019 to better align VET curricula with employers' needs. Projects financed by the European Social Fund support this trend and take into account the specific needs of regions, involving both schools and employers.

- Some $62 \%$ of the population have reported to have at least basic digital skills in 2019 (compared to an EU average of 58\%), but only $26 \%$ of people had above-basic digital skills (EU average: $33 \%$ ). The Work 4.0 Action Plan designed by the government in cooperation with social partners was being rolled out with specific measures to adapt to technological change and develop workers' digital skills (see "School Improvement" and "Governance" in this profile for other measures).

In May 2020, the Council of the European Union proposed the following country-specific recommendation to the Czech Republic, with regard to education and training: "support employment through active labour market policies, the provision of skills, including digital skills, and access to digital learning". Subject to its endorsement, this recommendation will be formally adopted in July 2020. 


\section{EQUITY AND QUALITY: GROWING ECEC ENROLMENT, BUT INEQUITIES HAVE PERSISTED ACROSS THE SYTEM}

The Czech Republic has combined performance in reading around the OECD average, with below-average PISA equity indicators. In PISA 2018, the Czech Republic had a smaller share of students performing below the baseline level in reading (PISA Level 2), at $20.7 \%$, compared to $22.6 \%$ on OECD average. The share of high performers (Level 5 or above) was similar to the average at $8.2 \%$, compared to $8.7 \%$. Czech performance in both science and mathematics was above average in PISA 2018, with slightly higher-than-average shares of highperforming students. Gender differences in reading were around average, with girls outperforming boys by 33 points (the OECD average difference is 30 points). However, socio-economic status in the Czech Republic had one of the largest impacts on reading performance in the OECD in PISA 2018, explaining $16.5 \%$ of the variance, compared to $12 \%$ on average. Furthermore, the score point difference between advantaged and disadvantaged students' reading performance grew more than anywhere else in the OECD between PISA 2009 and PISA 2018.

Early childhood education and care (ECEC) policies can increase the equity of education systems. In the Czech Republic, children typically begin pre-primary education (mateřské školy or Kindergarten) at 3 years old, and attend for three years. Younger children generally attend childcare institutions under the responsibility of the Ministry of Labour and Social Affairs (MPSV). The Czech Republic has worked to increase enrolments, with support from EU funds, and ECEC is now compulsory for 5-year-olds (see "Recent policies and practices"). Between 2010 and 2017 , enrolment rates for $3-5$ year-olds increased by 9 percentage points to $88 \%$ (the OECD average was $87 \%$ ). However, at $6 \%$, enrolment of children under 3 years old was well below the OECD average of $26 \%$. Prior to the first year of basic education, children with additional educational needs or those granted a postponement of compulsory education can attend a one-year preparatory class (prípravné trí́dy) offered within primary schools to support transition to basic education.

According to OECD evidence, some system-level policies seen in the Czech Republic can favour equity, such as a longer period of compulsory education, limited ability grouping and low grade repetition. Compulsory education begins at age 5 and ends at 15 in the Czech Republic and, in PISA 2015, only 5\% of Czech 15-year-olds reported having repeated a grade during their education, compared to $11 \%$ on average. Principals' reports in PISA 2015 indicate that only $3.5 \%$ of 15 -year-olds attended schools with ability grouping for all subjects, less than half the average share. However, in the Czech Republic, students are first tracked into different educational pathways at age 11, when they choose between grammar schools (subject to entrance examination), comprehensive schools or conservatoires. This is five years earlier than the modal age of first tracking for OECD countries. Such a practice may prematurely restrict students' educational options: in PISA 2018, the level of academic inclusion in the Czech Republic was among the lowest in the OECD, with an index value of $54 \%$, compared to an average of $71 \%$. The OECD (2016) identified this practice, together with the reduced curriculum offered by some schools and a strong special education sector, as features that favour social selectivity by school type.

The Czech Republic has a substantial Roma population and has undertaken efforts to improve their educational outcomes. Roma students experience considerable disadvantage compared to the rest of the population: according to the EU Agency for Fundamental Rights (2018) Roma students' participation in ECEC, in the Czech Republic, from the age of 4 was well below their peers in 2016 with persistently high non-completion rates across all education levels. Further, evidence (2017) suggested that Roma children are disproportionately misdiagnosed to be placed in special education schools, and that informal segregation occurs through school choice and admissions practices. The OECD (2016) reported that, for the effective integration of Roma students in mainstream education, additional support for schools is required, including capacity building and targeted financial resources. Inclusive education is an ongoing priority of the Ministry of Education Youth and Sports (MŠMT) (see "Recent policies and practices").

\section{Key strengths and challenges in equity and quality (pre-crisis analysis)}

\section{Key strengths}

- The Czech Republic had around average performance in reading, and above-average in mathematics and science, in PISA 2018.

- Efforts have been successfully undertaken to expand ECEC participation among 3-5 year-olds.

\section{Key challenges}

- Addressing differences in student performance by ethnicity or socio-economic background.

- Ensuring that tracking students into different educational pathways from a young age does not limit educational outcomes for certain groups. 


\section{0 | No. 11 - EDUCATION POLICY OUTLOOK IN THE CZECH REPUBLIC}

\section{Recent policies and practices}

An amendment (2017) to the Education Act extended compulsory education to 5-year-olds, with a legal entitlement to a place in ECEC from the age of 4. As of 2018, municipalities must also provide a place for all 3-year-olds; however, planned extension to 2-year-olds by 2020 was repealed (2018) due to capacity concerns. A dedicated fund has been supporting expansion (see "Funding"). For younger children, the MŠMT has been in discussions with the MPSV for a more transparent and coherent system and issued information supporting providers. To increase enrolment, the EU has suggested raising awareness among families and municipalities as to the benefits of children's participation in ECEC.

An amendment (2015) to the Education Act legally entitled students with special educational needs (SEN) to mainstream education with support. Only those with severe disabilities, whose needs cannot be met in mainstream schools, can be educated in specific institutions, and this by recommendation of a school counselling facility or written request of the student or their guardian. Within seven months, 14000 students had transferred to mainstream primary schools but the EU (2018) reported increases in the administrative burden on schools and a need for specialised training. With EU support, the inclusive and quality education in territories with socially excluded localities project (2016-22) strengthens strategic planning for inclusive education across governance levels; national action plans focus on capacity building. An amendment (2019) clarifies the extra support to be put in place by schools, to reduce their workload. However, the Council of Europe (2018) raised concerns that this may counteract positive intentions of former legislation; the Czech Republic's response (2019) emphasised that the number of SEN students entering mainstream schools is growing annually by $1-2 \%$. During the COVID-19 pandemic, targeted supports for SEN students were introduced at national and local level (see Spotlight 1).

For Roma children, the effect of such efforts appears limited. According to an EU report (2018), in 2017/18, Roma comprised around $30 \%$ of children educated in programmes for those with mild SEN. Although less than in 2016/17, given that Roma account for under $3 \%$ of all students, this suggests ongoing segregation. The share of Roma children in schools with non-Roma peers has not increased. Good practices are developing: data collection was strengthened and two annual grant programmes support Roma children at all levels, addressing issues such as attendance, parental engagement and early school-leaving. The Czech Ombudsman's Recommendation on the joint education of Roma and non-Roma (2017) emphasised the role of municipalities in supporting schools to actively confront segregation; the EU (2020) reported no evidence of implementation.

\section{Figure 3. Selected equity and quality indicators for the Czech Republic, PISA 2018}
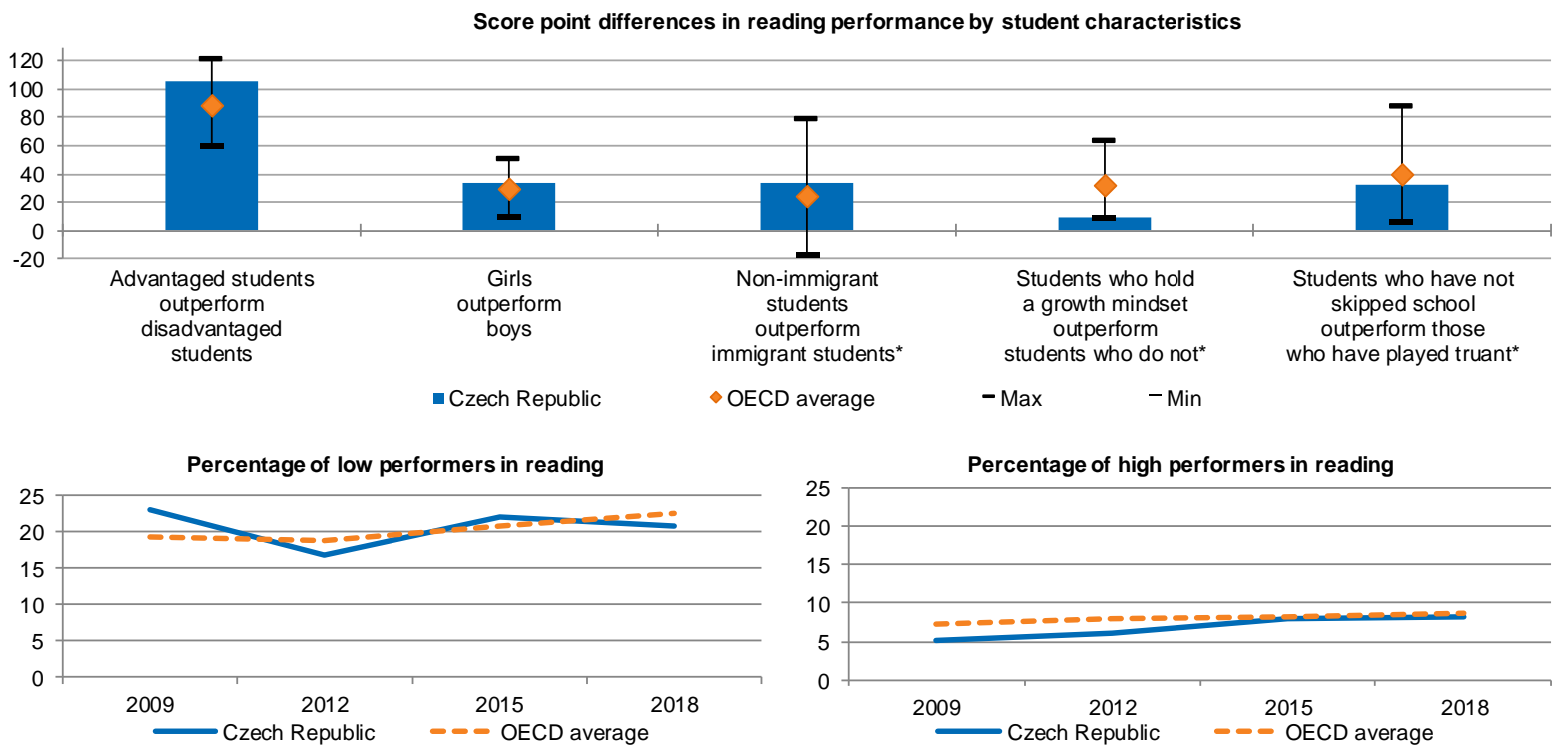

Notes: "Min"/"Max" refer to OECD countries with the lowest/highest values; ["] Score point difference after accounting for students' socio-economic status and language spoken at home; the share of immigrant students in the Czech Republic is $4.1 \%$, compared to the OECD average of $13.1 \%$. Sources: OECD (2019), PISA 2018 Results (Volume I): What Students Know and Can Do, PISA, OECD Publishing, Paris, https://doi.org/10.1787/5f07c754-en; OECD (2019), PISA 2018 Results (Volume II): Where All Students Can Succeed, PISA, OECD Publishing, Paris, https://doi.org/10.1787/b5fd1b8f-en; OECD (2020), PISA 2018 Results (Volume III): What School Life Means for Students' Lives, PISA, OECD Publishing, Paris, https://doi.org/10.1787/acd78851-en. 


\section{PREPARING STUDENTS FOR THE FUTURE: HIGH EDUCATIONAL ATTAINMENT AND ADULT SKILLS, WITH TRANSITIONS TO BE STRENGTHENED}

A country's capacity to effectively develop skills and labour market perspectives can play an important role in the educational decisions of the population. Adults in the Czech Republic have high educational attainment and skill levels. In 2018, the share of 25-64 year-olds with lower secondary education as their highest level of attainment was among the smallest in the OECD, at $5.9 \%$, compared to an average of $14.4 \%$. Furthermore, adult scores in the OECD Survey of Adult Skills (PIAAC) 2012 were above average in both literacy and numeracy. These high skills and qualification rates have combined with low levels of unemployment, including for youth. Unemployment rates for 25-34 year-olds with only upper secondary or post-secondary non-tertiary education were among the lowest in the OECD in 2018, at $2.6 \%$, compared to $7.3 \%$ on average. Similarly, only $10 \%$ of Czech 15-29 year-olds were not employed or in further education or training (NEET) in 2018, below the OECD average of $13.2 \%$. However, gender differences exist: only $70 \%$ of $25-34$ year-old tertiary-educated women were employed in 2018, compared to $94 \%$ of tertiary-educated men. The OECD (2018) reported that female labour force participation reduces with childbirth, recommending reducing maximum parental leave, while expanding affordable and quality childcare.

In upper secondary education, the majority of students in the Czech Republic enrol in 4-year programmes, general or vocational, delivered by either the prestigious gymnasia and lyceums, technical secondary schools or conservatoires. These programmes are accessed via a common admissions test and lead to a general certificate of education and the Maturita examination, which provides access to tertiary education (see "Evaluation and Assessment"). Around one-third of students pursue a 2- or 3-year vocational programme, which leads to a vocational education and training (VET) certificate, and a very small number of students attend a 2-year programme in practical schools. Students from these pathways aiming to enter tertiary education must complete 2-year bridging courses; however, a report from the European Centre for the Development of Vocational Training (Cedefop) (2018) shows that they have a lower chance of graduating from higher education, as well as relatively high unemployment rates. Despite not being compulsory, the percentage of the population aged 25-34 with at least an upper secondary qualification was among the highest in the OECD in 2018 (see Figure 2). In 2019, according to Eurostat, the share of early leavers from education and training among 18-24 yearolds was $6.7 \%$ in the Czech Republic, well below the EU average of $10.3 \%$. Nevertheless, this marked a slight increase from $5.5 \%$ in 2014.

Vocational education and training (VET) can ease entry to the labour market, yet in many OECD countries VET programmes make insufficient use of workplace training. In the Czech Republic, practical training is mandatory in all 3- or 4-year upper secondary VET programmes, constituting $35-50 \%$ of instruction depending on the field. However, this has been predominantly school-based training as opposed to workplace experience. In $2016,73 \%$ of upper secondary students followed a vocational programme, the largest share in the OECD where the average was $44 \%$. Yet only $6 \%$ of vocational students enrolled in a programme with work-based learning. The OECD (2016) underlined some rigidity in the vocational offer, which has focused more on maintaining historic supply quotas than meeting shifting labour market demand. A further OECD study (2015) identified a reduction in participation rates as comparatively low labour market outcomes and more limited access to tertiary education encourage students towards general pathways. Recent efforts have aimed to overcome this (see "Recent policies and practices").

Higher education in the Czech Republic follows the Bologna model and includes university and professional education. At university level, students can enrol in a 3- or 4-year (typically 3-year) bachelor's programme before completing a 1- to 3-year (typically 2-year) master's. Alternatively, they can begin their tertiary education with a 4- to 6year (typically 5-year) master's programme. In recent years, the Czech Republic has increased levels of tertiary attainment, considerably (see Figure 2). However, according to students' reports in PISA 2018, socio-economically advantaged students were more than twice as likely as their disadvantaged peers to report expecting to complete tertiary education in the future, which was among the largest disparities in the OECD. This could have implications for social equality: in 2015, tertiary-educated individuals in the Czech Republic benefitted from one of the highest wage premiums ${ }^{2}$ relative to the upper secondary educated in the OECD, at $69 \%$ compared to $57 \%$ on average.

\section{Key strengths and challenges (pre-crisis analysis)}

\section{Key strengths}

- Czech adults have higher educational attainment and higher literacy and numeracy skills than on average across the OECD.

- Tertiary education qualifications lead to high employment rates and salary levels, particularly for men.

\section{Key challenges}

- Enhancing quality and labour market relevance in the VET sector.

- Improving student transitions between upper secondary pathways and into tertiary education, and ensuring equitable access. 


\section{2 | No. 11 - EDUCATION POLICY OUTLOOK IN THE CZECH REPUBLIC}

\section{Recent policies and practices}

The Czech Republic undertook several efforts between 2016-20 to improve VET programmes, with a particular focus on strengthening collaboration between schools and employers. The MŠMT produced a recommendation for a unified approach to establishing collaborative contracts (2015) between schools and employers. This has included tax incentives for employers, for which the number of applicants doubled between 2014 and 2017. An amendment (2017) to the Education Act required schools to ensure an element of practical training occurs in the workplace and introduced a formal obligation for schools to cooperate with employers in curriculum design, practical training, final assessment and teacher development. The Modernisation of VET through the Collaboration with Industry project (2017-20), with financial support from the EU, aimed to improve the quality of VET in technical secondary schools by setting up exchanges between schools and industrial companies to foster students' increase motivation to take up studies in technical disciplines. As of early 2020, over 1150 study modules and 47 cooperation plans between schools and employers had been developed.

The revision of the upper secondary VET curriculum has been ongoing alongside wider curriculum reforms (see "Governance"). In particular, revisions have aimed to ensure that work-based learning elements successfully link VET curricula with the criteria laid out in the National Register of Qualifications (see below) and that schools have more flexibility to increase the level of practical training included in VET programmes.

The National Register of Qualifications (NSK, 2007), linked to the European Qualifications Framework (EQF), has aimed to better align the National System of Occupations (2004) with qualifications and respond to changing labour market needs. The development and implementation of the NSK was undertaken with financial support from the EU; updates continue through national funding and with the participation of employers' representatives. The National Referencing Report of the Czech Republic (2011, updated 2015), identified that the Czech Republic fulfilled the criteria for the implementation of the EQF, but should advance the development of a National Qualifications Framework (NQF) to support the MŠMT in validating learning outcomes across the system. Progress in this regard has been limited, although talks have been in progress to include the NQF in higher education quality assurance processes and some institutions have used the NQF to develop courses.

The reform of the Higher Education Act (2016) established a quality assurance system in line with the Standards and Guidelines for Quality Assurance in the European Higher Education Area (2015). The amendment required higher education institutions (HEls) to establish quality assurance committees responsible for developing internal quality assurance and self-evaluation systems. This has been monitored through annual institutional reporting. Additionally, these internal processes became subject to external approval by the National Accreditation Bureau (NAB, 2016), according to new standards. This independent body replaced the previous Accreditation Commission, gaining more autonomy and institutional weight. The institutional accreditation for field of study, a higher level of accreditation for HEls, was also introduced; as of early 2020, $13 \mathrm{HEls}$ had been awarded this, certifying their strong internal quality assurance practices and reducing their reliance on NAB accreditation processes. However, such changes require a considerable cultural shift, which takes time. Other measures include increasing study grants for disadvantaged students and the introduction of "professional profile" courses, which include work-based learning. At the time of writing, $8 \%$ of the newly accredited study programmes belong to this category and the share is growing.

Figure 4. Percentage of 15-29 year-olds in education and not in education, by employment status, 2018

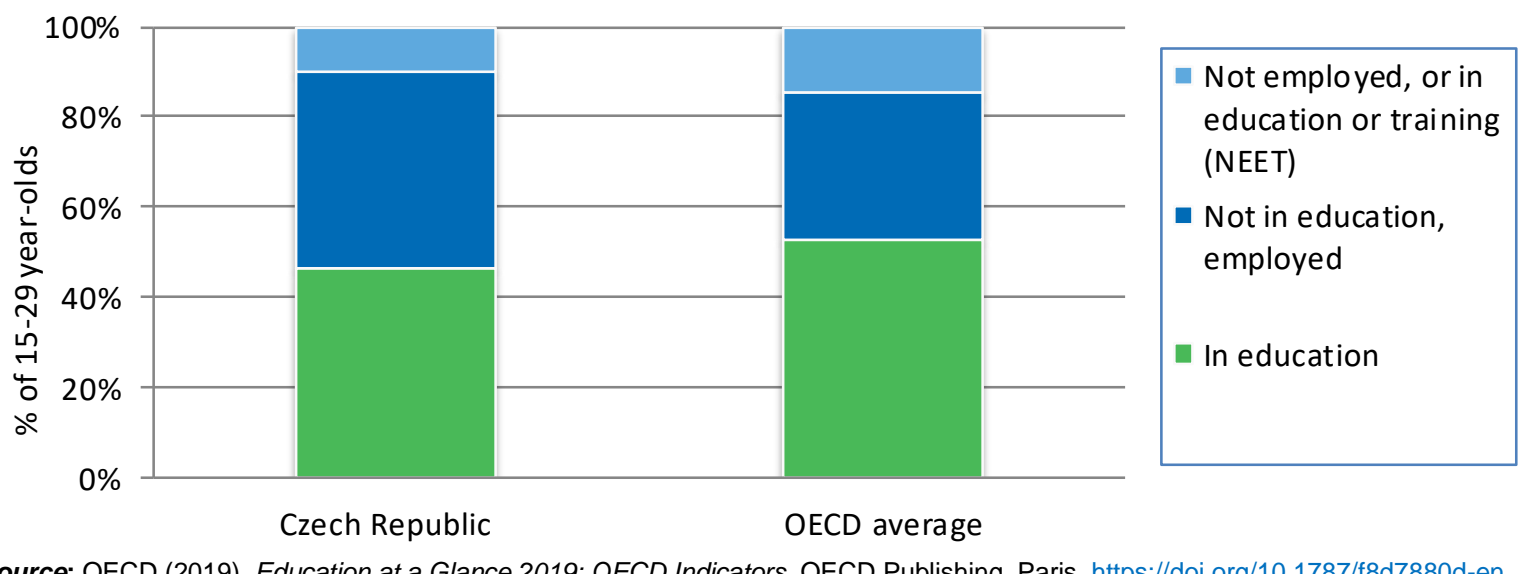

Source: OECD (2019), Education at a Glance 2019: OECD Indicators, OECD Publishing, Paris, https://doi.org/10.1787/f8d7880d-en. 


\section{SCHOOL IMPROVEMENT: EFFORTS HAVE BEEN UNDERTAKEN TO IMPROVE WORKING CONDITIONS FOR TEACHERS}

Developing positive learning environments for students which enable school leaders and teachers to succeed is essential for raising achievement in schools. Reports from Czech principals, teachers and students in PISA 2018 and TALIS 2018 present a mixed picture. In PISA 2018, self-reports indicated that students in the Czech Republic perceived their teachers to be less supportive than students elsewhere in the OECD, with an index of teacher support of -0.22 , compared to the average of 0.01 . They also perceived classroom behaviour to be less conducive to learning than in other OECD countries, with an index of disciplinary climate of -0.02 compared to 0.04 on average. However, according to teachers' and principals' reports in TALIS 2018, class time spent on actual teaching and learning in the Czech Republic, at $84 \%$, was above the OECD average of $78 \%$, meaning less time spent on administrative tasks and keeping order. In addition, a smaller share of 15-year-olds reported skipping at least one day of school in the two weeks prior to the PISA 2018 test, at $10.5 \%$ compared to the OECD average of $21.3 \%$.

Attracting, retaining and developing good-quality school leaders is critical for improving the quality of learning environments and promoting effective school leadership. In the Czech Republic, only teachers with a certain number of years of teaching experience can apply for a school leadership position. As set out in the Framework of professional development for pedagogical workers (2017), prospective school leaders must complete 100 hours of school management studies, including a practicum of at least 15 hours. In PISA 2015, Czech principals' self-reports suggested they engage in leadership activities related to teaching and learning slightly more than on average across the OECD, with a score of 0.04 on the index of instructional leadership. However, in TALIS 2018, a much smaller share reported having participated in instructional leadership training than on average (63\%, compared to $83 \%)$. In contrast, $95 \%$ reported that they had followed school administration or principal training programmes, before or after taking up the position, compared to $87 \%$ on average. The OECD (2016) recommended that school leaders in the Czech Republic could be better supported to develop their role as instructional leaders.

A strong supply of highly-qualified and engaged teachers is vital in every education system. Teachers in the Czech Republic have comparatively high levels of formal qualification. Except for vocational programmes, aspiring teachers must generally hold a master's level qualification and, according to principals' reports in PISA 2018, $88 \%$ are certified to this level, twice the OECD average share. Universities define initial teacher education (ITE) curricula, but a practical component is compulsory. In TALIS 2018 , however, only $62 \%$ of Czech lower secondary teachers reported that content, pedagogy and classroom practice had been a component of some or all subjects in their ITE, compared to the OECD average of $79 \%$. All education staff in the Czech Republic must regularly engage in professional development and teachers are entitled to twelve days' study leave per school year. Accordingly, nearly all (97\%) Czech teachers reported having undertaken professional development in the twelve months prior to the TALIS 2018 survey, although only $78 \%$ judged this to have had a positive impact on their teaching, compared to OECD averages of $94 \%$ and $82 \%$, respectively. The Czech teaching workforce is ageing: in both primary and secondary education, almost half are aged 50 or over (44\%, compared to an OECD average share of $36 \%$ ).

Teaching conditions in the Czech Republic include close-to-average class sizes, fewer teaching hours and low salaries. In 2017, there were typically 21 students in primary and 22 students in secondary school classes in the Czech Republic. Typical net teaching time in 2018 at both primary and lower secondary level was 617 hours $^{3}$, compared to respective OECD averages of 783 and 709 hours. At the same time, lower secondary teachers earned $64 \%$ of the average salary of other Czech full-time, full-year workers with similar education in 2015, compared to an average ratio of $88 \%$. The government has since introduced salary increases (see "Recent policies and practices"). However, teacher salary progression remains flat and, despite extensive efforts from 2010-17, there is still no clear system of career progression for teachers. In TALIS 2018, 74\% of lower secondary teachers in the Czech Republic reported that they would still become a teacher if they could choose again, similar to the OECD average. Conversely, just $16 \%$ felt that the teaching profession was valued in society, compared to $26 \%$ on average.

\section{Key strengths and challenges in school improvement (pre-crisis analysis)}

\section{Key strengths}

- Nearly all Czech principals participate in school administration or principal training programmes.

- Czech teachers regularly engage in professional development, with designated time built into the school year.

\section{Key challenges}

- Strengthening learning environments in schools to improve conditions for students.

- Addressing the relatively low salaries and perceived status of teachers to ensure the continued supply of quality educators. 


\section{4 | No. 11 - EDUCATION POLICY OUTLOOK IN THE CZECH REPUBLIC}

\section{Recent policies and practices}

Contracts for school leaders moved from six-year fixed-term contracts to permanent contracts through an amendment (2015) to the Education Act. However, the concept of a six-year mandate and the appointment process for school leaders remain in place, in principle. After 5.5 years, the school founder can open an appointment process to select a new principal. If the current principal is not selected, he or she remains an employee at the school and may work as a teacher. The EC (2019) reported that half of open posts have a single applicant, and that principals in office often reapply at the end of their mandate. A further amendment (2019) specifying the rules of selection for principals, aimed to make decisions more quality-driven by increasing the size of the selection panel and introducing the opportunity to use different types of assessment tools.

Addressing the comparatively low teacher salaries in the Czech Republic has been a priority of the Education Strategy 2020 (see "Governance"). Since 2015, teachers' salaries have risen annually, with an increase in 2016 of $8 \%$ for teaching staff and of $5 \%$ for nonteaching staff. The Czech government implemented a programme to increase salaries by 15\% (2017). The 2019 education budget earmarked CZK 95 billion (Czech Koruna) for teacher salaries, an increase of CZK 16.1 billion from 2018, and constituting an average teacher salary increase of $10 \%$. The Czech Moravian Trade Union of Education Workers was influential in securing these commitments through the End of Cheap Teachers (2016) campaign, which included high-level negotiations with the government, as well as a social media campaign and discussions regarding strike action. However, given that salary increases have touched public sector workers in general over the same period, and that salary progression remains flat, these measures may not be sufficient to raise the attractiveness of the profession.

Through an amendment (2017) to the Education Act on the rights and obligation of teaching staff, the Czech Republic aims to better protect teachers from psychological and physical intimidation. This followed findings from the Czech Schools Inspectorate (2015) that $36 \%$ of secondary schools experienced difficulties with verbal, and in some cases physical, aggression against teachers. This was accompanied by support tools for school leaders from the National Pedagogical Institute (NPI). Furthermore, clear guidelines for school management regarding how to deal with such situations are integrated within the school management training required of school leaders.

In 2012, the Czech Republic established a free online portal for educators, supervised by NPI, where users can add teaching material. By 2020, the portal listed nearly 8000 methodological contributions, over 10000 digital teaching materials, a suite of digital tools (Web 2.0), as well as online courses and webinars; it had 31000 registered users in 2019. Through the Supporting Capacity Building for Basic Literacies in Pre-primary and Basic Education - Supporting Teaching Practice project (2016-21), with EU financial support, the Czech Republic is building teachers' capacity to develop students' basic literacies, including digital literacy and computational thinking. In 2019, professional development modules fostering the use of open digital resources and teachers' digital skills were added. For the latter, a digital tool based on the European Framework of Digital Competences for Educators (2017) maps teachers' digital competences through self-evaluation. Such efforts provided a valuable resource base during the shift to online learning caused by the COVID-19 pandemic (see Spotlight 1).

Figure 5. The learning environment according to students, PISA 2018

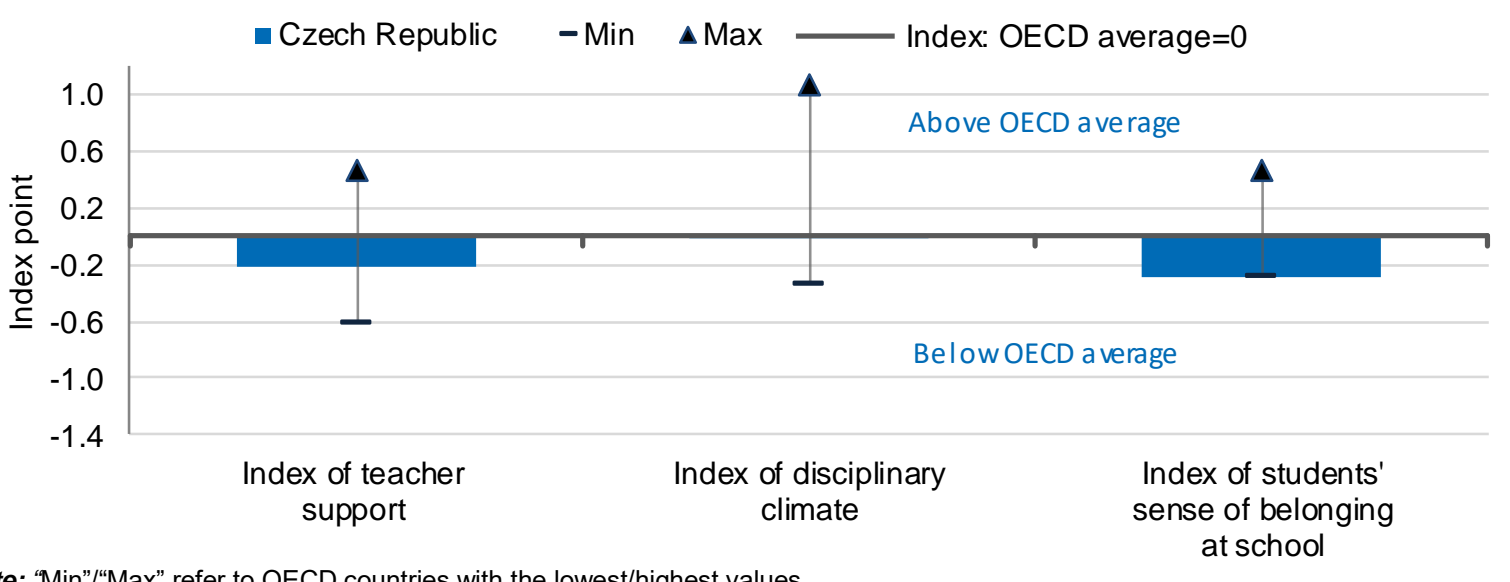

Note: "Min"/"Max" refer to OECD countries with the lowest/highest values

Source: OECD (2020), PISA 2018 Results (Volume III): What School Life Means for Students' Lives, PISA, OECD Publishing, Paris, https://doi.org/10.1787/acd78851-en. 


\section{EVALUATION AND ASSESSMENT: EFFORTS TO ESTABLISH AND FURTHER DEVELOP CONSISTENT MECHANISMS AND FRAMEWORKS}

Defining strategies for evaluation and assessment is an important step towards improving student outcomes and developing a better and more equitable school system. System evaluation can provide evidence to help decision makers craft informed policies and increase the transparency of education system outcomes. In the Czech Republic, aggregated student outcomes from international assessments are the main instrument for system evaluation, along with school-leaving examinations, standardised tests in grades five and nine, and sampled tests in primary education (see "Recent policies and practices"). The Centre for Evaluation of Educational Achievement coordinates these and analyses the outcomes. Both central and regional governments publish annual reports on the development of the education system. However, within the Czech context of considerable decentralisation to the school level (see "Governance"), the OECD (2016) previously identified the limited availability of system-level information regarding educational outcomes and equity as a factor which could hinder policy monitoring. Overall, $50 \%$ of students in the Czech Republic in PISA 2015 attended schools where principals reported that administrative authorities track achievement data over time (the OECD average is $71 \%$ ).

The Czech School Inspectorate (ČŠI) conducts external inspections of educational institutions from pre-primary to upper secondary level. The national criteria for school evaluation is annually approved and published by the MŠMT. Each school should be evaluated every six years by the ČŠl, through 14 regional school inspectorates. Schools found to be requiring further support must create an improvement plan that is overseen by the municipality or region and later by the Čsı. Schools are also required to undertake internal self-evaluations, and can define their terms, structure and content. They are expected to publish annual activity reports too. Although the preparation of school development plans is not common practice in the Czech Republic, some schools do engage in such strategic planning. A project to establish uniform processes for school-level strategic management and planning (2016), developed with the support of European funds, is ongoing. According to principals' reports in PISA 2015, schools in the Czech Republic are more likely than average to conduct self-evaluations ( $97 \%$ compared to an OECD average of $93 \%)$, but less likely to receive external evaluations $(61 \%$ compared to $75 \%$ ). The OECD (2016) encouraged the Czech Republic to continue efforts to transform the focus of external evaluations from compliance to improvement and this has been an area of policy action (see "Recent policies and practices").

According to OECD evidence, teacher appraisal can strengthen professionalism and performance if it includes both improvement and career progression components. Teacher appraisal seems to take place in a high share of Czech schools: in TALIS 2018, some $82 \%$ of school principals reported conducting formal appraisals of teachers at least once a year, compared to an OECD average of $63 \%$. In addition, between TALIS 2013 and TALIS 2018, there was a considerable increase in the rate of peer appraisal in the Czech Republic, with a 14 percentage-point increase in the share of principals reporting that their teachers were appraised by a mentor or a teacher colleague. Some $63 \%$ of teachers' principals reported that formative discussions take place following formal appraisal, the highest instance in the OECD. However, only $33 \%$ reported that appraisal always led to the elaboration of a development or training plan. With no formal national requirements or procedures, approaches may differ from school to school. The OECD (2016) has previously found that information on the procedures and criteria is limited.

Strong student assessment practices can inform and shape effective initiatives for educational improvement. In the Czech Republic, students' learning is assessed via both external examinations and teacher assessments. As of 2016/17, a unified entrance examination for upper secondary schools was put in place and to graduate from this level, students have to pass one of three final examinations depending on the pathway (see "Recent policies and practices"). However, evidence suggests improvement-focused teacher assessment is underdeveloped in the Czech Republic: in 2015, only $34 \%$ of students were in schools where principals reported that student assessments were used to identify aspects of instruction or the curriculum that could be improved, compared to the OECD average of 59\%. Furthermore, in PISA 2018, students perceived the level of teacher feedback on their learning to be among the lowest in the OECD, with an index of teacher feedback of -0.24 compared to an OECD average of 0.01 . Nevertheless, this may be changing: in the Czech Republic, teacher engagement in professional development related to student assessment increased by 16 percentage points between TALIS 2013 and TALIS 2018.

\section{Key strengths and challenges in evaluation and assessment (pre-crisis analysis)}

\section{Key strengths}

- A large share of teachers reported being appraised each year.

- Measures have been taken to introduce unified examinations at secondary level, which could provide useful data on educational outcomes.

\section{Key challenges}

- Strengthening system-level evaluation.

- Enhancing the link between teacher appraisal and development in a more systematic way.

- Making school planning and internal and external school evaluations more synergistic and conducive to improvement. 


\section{6 | No. 11 - EDUCATION POLICY OUTLOOK IN THE CZECH REPUBLIC}

\section{Recent policies and practices}

The Strategy for Education Policy of the Czech Republic (2014-2020) (see "Governance") includes as one of its three strategic priorities governing the education system in an accountable manner. Stated measures include strengthening external evaluation for school improvement and building connections between external and internal evaluation (schools' self-evaluation). In 2015, the Czech School Inspectorate (ČŠI) launched new Criteria for the Evaluation of the Conditions, Course and Results of Education (2015) to be applied in their evaluation of schools and pre-schools. Schools are supported to use the Criteria in their own self-evaluation processes and school leaders are held accountable through the Criteria to ensure that internal evaluation is consistently applied and well-designed.

In 2017, the ČŠI introduced the Complex System of Evaluation project (2017-20), with financial support from the EU. It aims to build on the methods, procedures and tools developed by the National System of Inspection Evaluation of the Educational System project (NIQES, 2011-15) and better integrate external and internal school evaluations through complementary methodologies. This includes, for example, supporting schools to share good practice in applying the evaluation criteria. The development of new methods, procedures and tools to assess key competencies also intends to support this, taking into account the socio-economic and geographic background of students and schools.

The standardised school-leaving examination, or Maturita (2011), has been under the authority of the Centre for Evaluation of Educational Achievement. For general and vocational upper secondary education, the state-set common component of the school-leaving examination is based on a compulsory subject (Czech language and literature) and a subject of choice (foreign language or mathematics). Furthermore, the student may take two additional non-compulsory examinations. For the school-set profile component, the school principal selects two or three compulsory subjects and two optional subjects, depending on the type of school. Results are passed on to the regional administrators who can decide whether to publish them or not. For the final examination from the three-year vocational programme leading to VET certificate, assessments are based on the Framework and the School Educational Programmes (see "Governance"); an amendment (2015) to the Education Act also introduced a single national standardised examination, prepared by the National Institute for Education. For students enrolled in other vocational upper secondary education programmes, the school principal decides on the topics covered for the final leaving examination.

The Czech Republic introduced full-cohort national standardised tests at grades five and nine (2011) under the authority of the ČŠl. Originally, these were planned to also serve as the basis for progression into a higher level of education, but it was later decided that they should only serve for low-stakes purposes. The tests aim to provide relevant audiences with information on learning outcomes at the student, school and system levels. They take place every four years in Czech and foreign languages, and mathematics. In 2017, the test took place

3700 basic schools and multi-year general academic schools; Čšl's analysis of the results (2017) highlighted the need to address underperformance of provincial schools and non-selective schools in comparison to schools in Prague and academically selective schools. Furthermore, there was evidence of frequent discrepancies between outcomes of the teachers' classroom-based assessments and those of standardised student assessments.

Figure 6. Percentage of students in schools where the principal reported assessments of students in national modal grade for 15-year-olds, PISA 2015

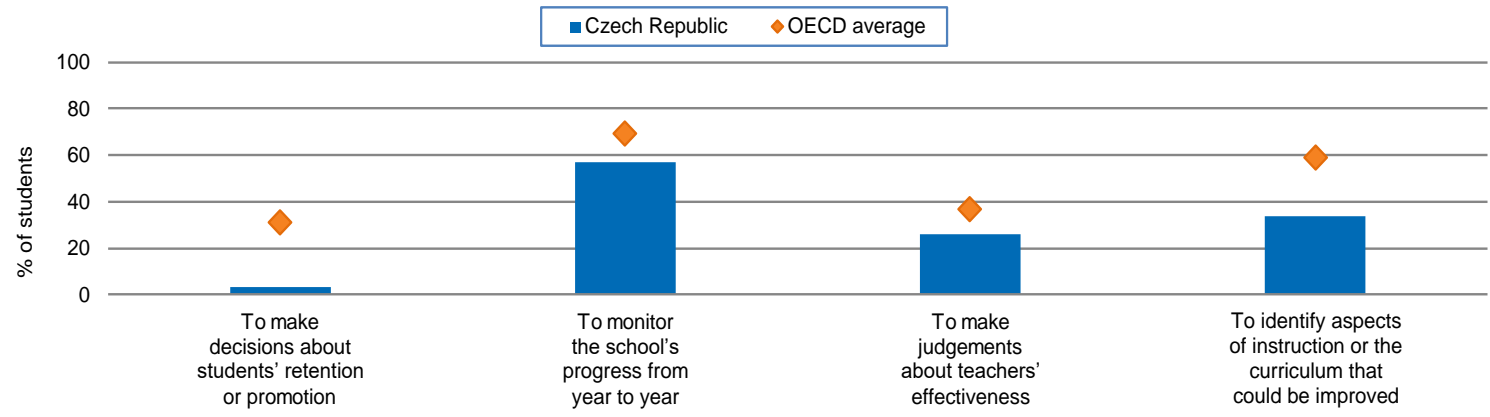

Source: OECD (2016), PISA 2015 Results (Volume II): Policies and Practices for Successful Schools, PISA, OECD Publishing, Paris, http://dx.doi.org/10.1787/9789264267510-en. 


\section{GOVERNANCE: BALANCING EDUCATION POLICY IN A FRAGMENTED SYSTEM}

The Ministry of Education, Youth and Sports (Ministerstvo školství, mládeže a tělovýchovy, MŠMT) is in charge of developing national education policy and long-term policy objectives that guide the system at all education levels (see Spotlight 4). The MŠMT cooperates with other ministries, such as the Ministry of Labour and Social Affairs and the Ministry of Industry and Trade, specifically on topics related to ECEC or labour market and vocational guidance. Other bodies relevant to the implementation of national education policy include:

- The National Pedagogical Institute of the Czech Republic (NPI, 2020) develops methodological supports and tools for teachers and institutions, provides professional development and coordinates curricular reform. NPI was formed through merging the National Institute for Education, Education Counselling Centre and Centre for Continuing Education of Teachers (NÚV) and the National Institute for Further Education (NIDV).

- The Centre for Evaluation of Educational Achievement (2006) develops standardised assessments to monitor learning outcomes at system level and undertakes assessment-related research.

- The Czech School Inspectorate assesses the quality of educational institutions (excluding higher education) and conducts monitoring and analysis for system level reporting.

- The National Accreditation Bureau for Higher Education (2016) is in charge of external evaluation, regulation and accreditation of higher education institutions and programmes.

- The Centre for Higher Education Studies, a public research institution, supports the higher education sector.

In the Czech Republic, consultation with stakeholders is required for certain policy areas, including the national educational programme and collective labour agreements. Key stakeholders include representative groups for teachers (e.g. Czech Moravian Trade Union of Education Workers), school principals (e.g. Association of Basic School Principals) and students (e.g. Czech Secondary School Union). The Association of Regions and the Union of Towns and Municipalities have been important collaborative platforms for educational governance, representing their members' views in national policy discussions. During the COVID-19 pandemic, the Czech Republic conducted surveys to gain insight into the experiences of various stakeholders within the education system (see Spotlight 1).

The Czech education system is highly decentralised. The 14 administrative regions must set long-term development plans for their school systems aligned with national steering documents, and organise upper secondary education in their jurisdictions. The 6000 municipalities organise and provide pre-school and basic education although given their small size, many only manage one school, and in some cases none at all. This, combined with the various school types and education pathways available to students, makes the Czech system highly differentiated and fragmented. The $\underline{O E C D}$ (2016) has also highlighted large educational differences between the 14 regions and the school network faces efficiency challenges due to the decline in the student population. A new funding reform aims to address this (see Spotlight 5).

Schooling decisions are largely made by the schools themselves. Since 2003, schools have been independent legal entities and have considerable autonomy. In 2017, administrative data suggested that around two-thirds of key educational decisions were taken at the school level in the Czech Republic, which was close to twice the OECD average share. Of the remaining one-third, the majority of decision making took place at local level, with central administration responsible for only $2 \%$ of decisions, compared to $24 \%$ on average (see Figure 7 ). Regarding curriculum, schools develop contextually relevant School Education Programmes (SVPs) based on a key national steering document, the Framework Educational Programme. SVPs are developed by a school team led by the principal. Primary, secondary and higher vocational education schools are legally required to have a school council, with representatives of the school founder, the staff body and parents.

The Czech higher education system is comprised of university-type institutions offering courses up to doctoral level, non-university types offering largely bachelor's programmes, and tertiary professional schools; each of these may have public or private status. Policy has been steered via the Long term plan for the activities of HEls 2016-2020 and its accompanying annual implementation plans, but ultimately institutions have a high level of autonomy.

\section{Key strengths and challenges in governance (pre-crisis analysis)}

\section{Key strengths}

- A high level of school autonomy which can allow for greater responsiveness in educational delivery.

- Regional and municipal platforms allow for collaboration within a highly decentralised system.

- Key steering documents are in place to guide decision making from pre-primary to tertiary.

\section{Key challenges}

- High regional variance in education performance.

- Education governance is fragmented, with low capacity in some regions or municipalities.

- Changes in the student demographic call for a need to improve efficiency in the school network. 


\section{8 | No. 11 - EDUCATION POLICY OUTLOOK IN THE CZECH REPUBLIC}

\section{Recent policies and practices}

The Long-term Plan for Education and the Development of the Education System (2015-20) built on the strategic aims of the previous plan (2011-15) and is based on the Strategy for Education 2020 (2014). Measures include increasing access to pre-school education, providing more resources for students in secondary VET, enhancing school facilities and raising teaching standards. Progress has been reported every two years. The new Long-term Plan (2019-2023) has three key objectives: improve pay for teachers, complete the curriculum review and implementation, and improve school management and facilities by strengthening cooperation between central and intermediate administrative levels. The Long-Term Plans do not cover higher education.

The NPI has been currently working on a revision of the Framework Education Programme (RVP) for kindergarten, primary and secondary schools, with implementation planned for 2023; these documents were last updated in 2007. The NPI intends to align expected learning outcomes with the National Register of Qualifications (see "Preparing students for the future"), provide schools with more time for curricular innovation and embed 21st century competencies alongside traditional subjects. The work plan for the first phase (2017-20) details three steps for the development of each curriculum area: 1) assess current national and international curricula and propose modifications. The research work for each subject area was published by NúV); 2) establish expert groups, with representatives from across the education sector, who engage in multi-round discussions to formulate the learning outcomes, and; 3 ) regularly consult groups with opposing views, formed mainly of teachers, and integrate their responses. The process is open to online public consultation. As of early 2020 , step one had been completed for over 50 subject areas and 21 expert groups were in operation, covering both specific subject areas and cross-cutting topics, such as special needs education and pre-school education.

The Digital Education Strategy to 2020 (SDV, 2014) has been put in place to embed digital technology across the education system. It was developed by the MŠMT in dialogue with educators, experts, the non-profit sector and other interested parties. The strategy has three key objectives: 1) introduce new approaches to learning through harnessing digital technology; 2) improve students' digital competence, and; 3) develop students' knowledge of information technology. Measures include ensuring equal access to digital infrastructure, stimulating and disseminating innovation, and improving public understanding of the importance of digital technologies in education. The implementation strategy has a three-stage action plan. The SDV Steering Committee (2016) meets monthly to manage the various activities carried out by the various working groups. Each of these bodies include representatives from the MŠMT and other formal and non-formal institutions, companies and non-profits. An interim evaluation (2019) found that all except one of the 42 planned activities were in progress, with 12 having been completed and 18 having made significant progress; the report awaits assessment by the management group of the MŠMT. Areas of action with the most progress appear to be establishing the conditions for developing digital skills among students and promoting innovation and sharing best practice. This likely proved particularly beneficial during the switch to online learning as a result of the COVID-19 pandemic (see Spotlight 1). At the same time, the report noted several delays largely due to a lack of financial or human resources and highlighted the important contribution of EU funds. There is also the challenge of digital education, not always seen as a priority among stakeholders.

\section{Figure 7. Percentage of decisions taken at each level of government for public lower secondary} schools (2017)

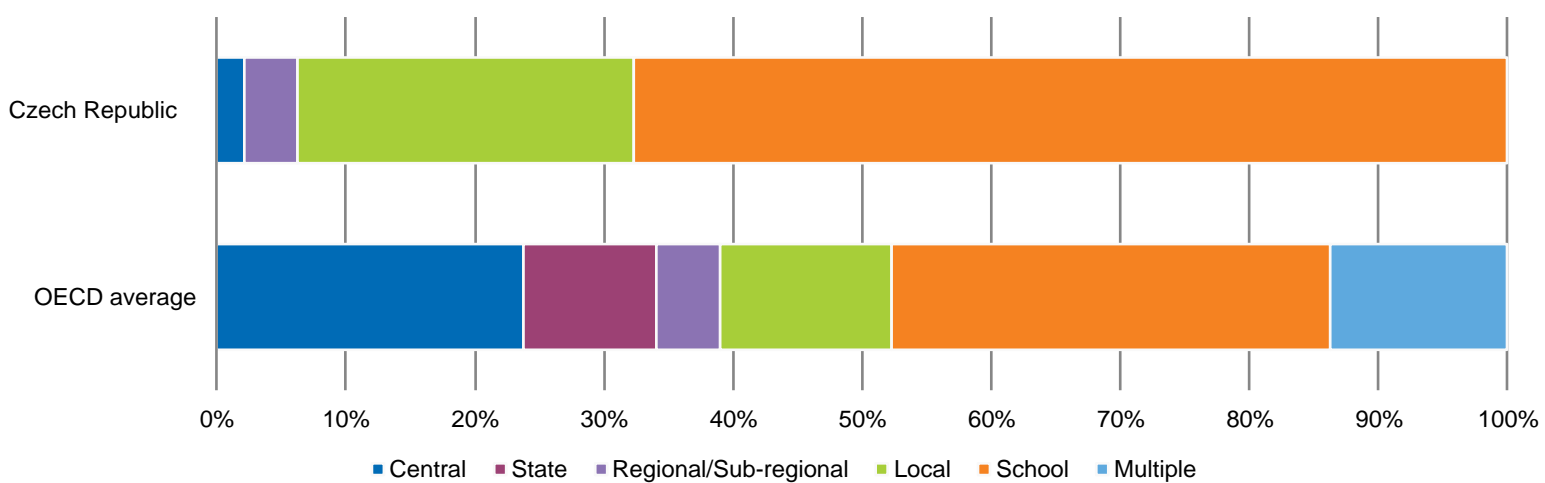

Note: This figure considers four domains of decision making: 1) Organisation of instruction; 2) Personnel management; 3) Planning and structures, and; 4) Resources.

Source: OECD (2018), Education at a Glance 2018: OECD Indicators, OECD Publishing, Paris, https://doi.org/10.1787/eag-2018-en. 


\section{Spotlight 4. Strategy for Education Policy of the Czech Republic until 2020 (Strategy 2020, 2014)}

Strategy 2020 guides education policy making in the Czech Republic. It defines the purpose of education through four primary objectives:

- Personal development that is conducive to the quality of human life;

- The preservation and development of culture as a system of shared values;

- The pursuit of active citizenship as a prerequisite for the development of society;

- Preparation for employment.

The Strategy's stated priority areas are:

- Reducing inequalities in education;

- Supporting quality teaching and teachers as the key prerequisite for this quality teaching;

- Governing the education system in an accountable and efficient manner.

The government started preparing the strategy in 2011, with priorities established through analyses of the Czech education system by national and international experts, as well as comparative studies and analysis of system-level data. An independent evaluation of the implementation of existing strategic and policy documents also informed the analysis in order to learn from previous experiences. The government included key stakeholders and the general public from early on in the development process in order to make it open from the start. In particular, the general starting points were opened up to broad public debate which then informed the writing of the final document.

The OECD (2016) previously reported that the three strategic priority areas were pertinent to the needs of the Czech education system. It also praised the fact that four different Ministers of Education from different political parties had contributed to the development of the strategy, which helped it to be perceived as a non-partisan framework. However, the OECD also identified a number of challenges for the successful realisation of the strategy. In particular, securing adequate funding was highlighted as a major challenge, exacerbated by the conclusion of some European funding programmes, which posed problems for central and regional administrations. Aligning national funding to ensure initiatives are sustainable would be a major step on the path to success. The Czech Republic's Operational Programme for Research, Development and Education, agreed and in financial collaboration with the EC, makes up one of the principal funding streams for the implementation of the specific measures of the Strategy.

The Czech Republic established a website for Strategy 2020, centralising all documentation and information related to the preparation, implementation and evaluation of Strategy 2020, and various monitoring mechanisms have been employed to assess the progress and impact. Since 2015/16, as part of its annual report, the Czech School Inspectorate (ČŠl) includes overviews of the development of the implementation of the strategy. Additionally, an external evaluation of interim progress (2018) was published. While this evaluation supported the Strategy's three priorities as still relevant, it also found that the objectives were too often top-down measures that lacked the consent and understanding of key stakeholders. Key recommendations for the second phase of the strategy included improving communication between all stakeholders and strengthening administration at all educational levels, as well as more concrete measures including:

- Updating the objectives and content of education to suit the demands of the 21 st century;

- Strengthening methodological support for teachers;

- Improving financial recognition of quality work among educators;

- Better defining the role of vocational education colleges;

- Systematising ECEC provision for children from the ages of 0-6;

- Reducing the administrative burden on educators through simplifying regulatory procedures.

In 2019, preparations began on the development of the 2030+ Strategy. The MŠMT appointed an eight-member expert group to establish the core of the strategy; the same year, a wide public consultation was launched to inform their work. The expert group held 17 round tables in different regions to engage with the public on the main challenges facing the education system. The main guidelines were published in 2019. Following this, the work moves to define how objectives and priorities are to be achieved. The MŠMT plans to present the final Strategy to the Government for approval in mid-2020. 


\section{FUNDING: LOW LEVELS OF EDUCATION EXPENDITURE, WITH CHANGES TO ALLOCATION MECHANISMS}

Overall expenditure on education in the Czech Republic has been low in international comparison, including as a proportion of national wealth. Between 2011 and 2016, spending on education did not match growth in national wealth, so that the expenditure on primary to tertiary education as a proportion of gross domestic product (GDP) actually decreased by 16 percentage points. In 2016, the Czech Republic's expenditure on primary to tertiary education was 3.5\% of GDP, one of the lowest shares in the OECD, where the average was $5 \%$. Furthermore, annual per-student spending was belowaverage across the system in 2016 with the largest deficit at primary level (USD 5104 per student compared to an average of USD 8 470). Nevertheless, partly due to a decline in the student population, there was a 24-point increase in per-student spending at primary, secondary and post-secondary non-tertiary level between 2005 and 2016. The Czech Republic has allocated the majority of funding to secondary education: $1.7 \%$ of GDP funds secondary education, compared to $0.5 \%$ for pre-primary, $0.8 \%$ for primary and $0.6 \%$ for tertiary also in 2016 . Given the proven higher returns to education for younger children, this may contribute to inefficiencies.

As elsewhere in the OECD, the majority of educational spending in the Czech Republic comes from public sources. The proportion of expenditure from primary to tertiary coming from private sources (including international sources) was below the OECD average in 2016, at $13.9 \%$ compared to $17.4 \%$. This share remained stable between 2010 and 2016 , whereas the OECD average share of private funding in education increased by 2.5 percentage points.

Funding allocations to primary and secondary schools in the Czech Republic are primarily the responsibility of the central and regional governments. Funding for direct costs (e.g. staff salaries and professional development, or material resources) is the largest share of these allocations and comes from central funds. Prior to 2020 , these were initially allocated to regions, and then by regions directly to schools, in the case of basic education, or directly to schools, in the case of secondary education. The initial transfer was based on a simple per-student allocation, and the regional transfers were determined through more complex criteria which were adjusted annually. From 2020, this has been adjusted (see Spotlight 5). Locally-raised funds (regional or municipal, depending on the education level) cover schools' operational costs; regions and municipalities are also responsible for separate funding streams for investment projects. As a result, there are many different sources of school funding (state, regional and municipal budgets; school-raised funds, donations and parental contributions). This variety may inhibit the government's capacity to assess for equity in funding allocations. According to principals' reports in PISA 2018, a comparatively larger share of schools in the Czech Republic reported experiencing shortages in some areas which hinder their capacity to provide instruction. These areas were educational material $(31 \%)$ and teaching staff $(35 \%)$, compared to the respective OECD averages of $28 \%$ and $27 \%$. In the case of teaching staff, shortages were more acutely reported in disadvantaged schools. Furthermore, the OECD (2016) has previously found the national allocation system to be overly simplistic in that it does not take into account regional variations in class size and student characteristics. Conversely, the regional allocation system was deemed overly complicated, which may hinder dialogue around education priorities and inhibit change. The government is currently implementing funding reforms to address some of these issues (see Spotlight 5).

Public funding to tertiary education is mainly provided by the central government; higher education taught in the Czech language is free for national and international students. In 2016, the central government was the source of $97 \%$ of the total public funds devoted to tertiary education ${ }^{4}$ compared to an OECD average of $87 \%$. Expenditure on tertiary education institutions in the Czech Republic has fluctuated: it increased between 2005 and 2011, but fell more quickly than student numbers between 2011 and 2016, resulting in a 7 percentage-point decline in per-student spending over that period. According to an EU report on fees and support grants (2018), in the Czech Republic, students progressing normally in their studies only paid an annual administrative fee of EUR 100 in 2018/19. In 2016, only $1 \%$ of first- and second-cycle students received needs-based grants (only available to those under 26), which was one of the lowest rates across EU countries. Some $6 \%$ of students received a merit-based grant and $58 \%$ received accommodation grants, although these are only available to those studying outside their region.

\section{Key strengths and challenges in funding (pre-crisis analysis)}

\section{Key strengths}

- Per-student expenditure increased between 2010 and 2015 across all levels of education.

- Public funds guarantee access to education at all levels, including tertiary, where student fees are nominal.

\section{Key challenges}

- The Czech Republic allocates a lower share of GDP to education than elsewhere in the OECD.

- Per-student funding is low at all levels and is concentrated on secondary education despite the highest returns coming from lower levels.

- Funding allocation mechanisms could be more responsive to local and future needs. 


\section{Recent policies and practices}

The Czech Republic's Operational Programme Research, Development and Education (2014-20), co-financed by the EU, is a multilevel topical programme supporting projects addressing key challenges in education and research. It mirrors the priorities and objectives set out in the Strategy for 2020 and the Long-term Plan for Education and the Development of the Education System. The programme is led by the MŠMT and has so far supported 10986 projects focused on capacity for high-quality research, development of universities and human resources for research and development, and equal access to high-quality pre-school, primary and secondary education.

The Nursery and Basic School Capacity Development Fund (2014), which is supported by EU funds, receives applications from schools or kindergartens whose infrastructural capacity is failing to meet demand for provision for 3-6 year-olds. In this way, the urgency of demands can be assessed and the funds targeted accordingly. By 2018, 130 actions had been supported by the fund to the amount of CZK 1.5 billion. By 2022, the MŠMT intends to have enough capacity within the system to extend the universal guarantee of ECEC places to 2-year-olds.

A revised higher education funding system (2018) in the Czech Republic aims to improve higher education quality, enhance specialisation among institutions and programmes, and increase completion rates. It splits institutional funding into a fixed allocation and a performance-based allocation, with different criteria according to each institution's area of specialisation. The funding system also intends to stabilise finances for institutions and set incentives to evaluate the demand for specific study areas, as well as criteria for quality and performance assessment. Performance-based components include: performance in research and development (34\%); incoming students in mobility programmes (14.5\%); outgoing students in mobility programmes (14.5\%); graduate employment levels (16\%); and other indicators including students in fee-paying foreign language programmes, the institution's own revenue, and share of professors and associate professors on the staff $(20 \%)$. In 2019, discussions were underway regarding the introduction of additional performance indicators to the funding model.

The Czech Republic has also made efforts to increase funding at tertiary level, and in 2018, the state budget for higher education institutions (HEls) increased by CZK 3 billion. As part of these efforts, the Programme to Promote Mutual Cooperation between HEls has run annually from 2017 to 2020. Institutions, in groups of two or more, can apply to a central fund earmarked for projects related to quality assurance, international cooperation, and research activities, as well as other priority areas.

\section{Figure 8. Annual expenditure per student (2016) and recent trends, by level of education}

\section{Expenditure per student at different levels of education}

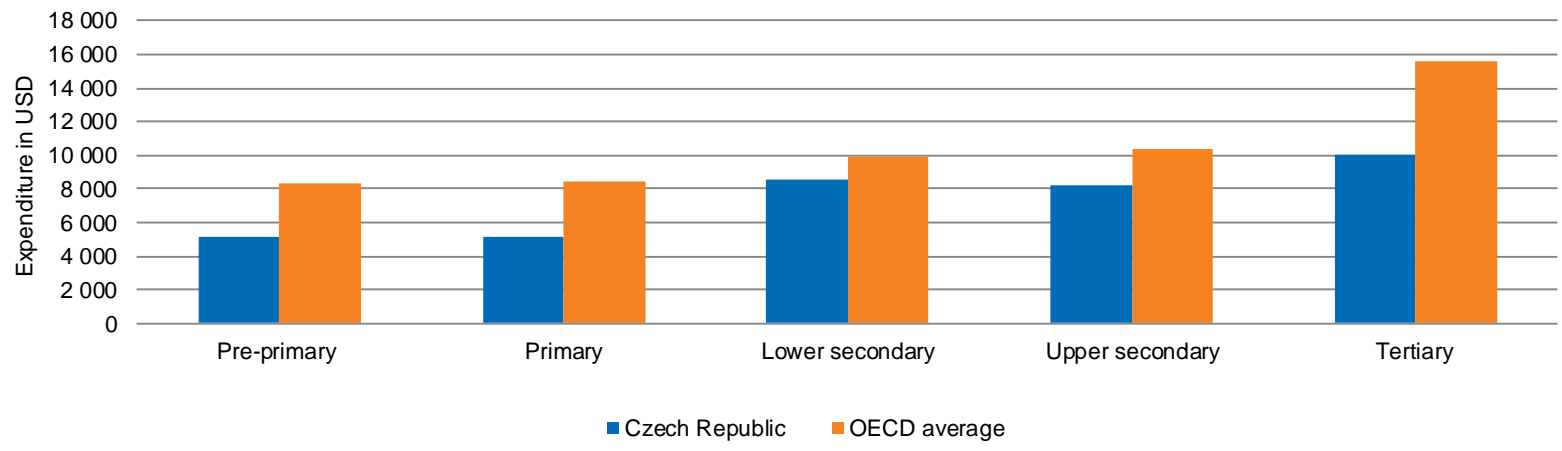

Change in expenditure per student, primary, secondary and post-secondary non-tertiary education $(2010=100)$

Change in expenditure per student, tertiary education $(2010=100)$
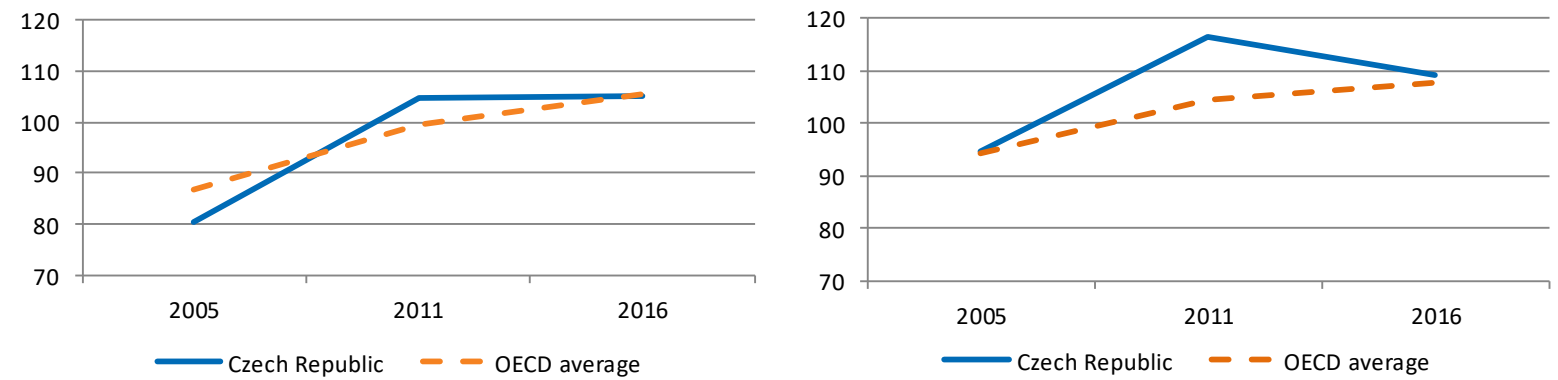

Source: OECD (2019), Education at a Glance 2019: OECD Indicators, OECD Publishing, Paris, https://doi.org/10.1787/f8d7880d-en. 


\section{$22 \mid$ No. 11 - EDUCATION POLICY OUTLOOK IN THE CZECH REPUBLIC}

\section{Spotlight 5. Regional Education Funding Reform (2020)}

In 2016, the MŠMT began developing a reform of the educational funding streams from central funds to regional and municipal institutions at pre-primary, primary and secondary levels (including public VET schools, but not private or religious schools, for whom the current system remains in place). The former system, first introduced in 1992, allocated funding based solely on the number of students enrolled in a school, resulting in large funding gaps between schools and across regions. Where possible, schools had high numbers of students per class and, at upper secondary level specifically, some schools admitted students who may not be suited to completing the academic programme in order to increase overall numbers. Finally, by not taking into account the age profile of teachers, the ability of principals to assign financial incentives fairly and adequately was constrained.

The reform has aimed to address some of the challenges and inequities brought about by the former system by integrating criteria related to instruction times for different courses, the number of classes, the number of students with special educational needs, and teachers' salary levels and teaching hours. As such, the new system is based on the financing of the real volume of teaching and the real level of teacher salaries; schools will receive funding for the extent of education provided, as opposed to the number of students enrolled. This enables a funding system which is more conducive to raising quality, as schools may reduce the number of children per class or employ more experienced teachers, where available, without any direct or indirect negative impact on funding.

Through this reform, schools will request financial resources from the state budget according to these criteria, and the MŠMT will assess the claims and allocate funding according to the amount defined by the regional standards. Furthermore, the MŠMT will set clearer rules regarding maximum and minimum class sizes and instruction hours to support a more transparent and stable transfer of funds. The reform also increases reporting requirements for schools and regional authorities, enabling greater oversight of the accuracy of reported data. The ČŠl supports the development of a methodology for this oversight. As before, schools will receive the central funds through the regional authorities in one package.

The Parliament approved the reform through an amendment of the Education Act (2017) and implementation was originally planned from January 2019. However, to allow more time for preparation, the government introduced a transition year starting from then, when additional financial support was provided to facilitate splitting up classes, balancing financial differences between schools in regions and ensuring sufficient staffing in nursery schools. Full implementation was set for early 2020.

To support with the transition to the new system, throughout 2018, 2019 and 2020, the MŠMT held seminars across all regions for school representatives as well as regional and municipal administrators. These have reached thousands of people. Furthermore, the MŠMT has established a dedicated online space for the reform on its website, publishing presentations from these seminars along with legislation and other documentation relating to the reform. The MŠMT has also developed mathematical models via which schools can calculate estimates of their funding allocations. In January 2020, the MŠMT made public all necessary information, calculations and data for all eligible schools - more than 8000 in total.

According to analysis from the European Centre for the Development of Vocational Training (2017), this measure is in line with the OECD (2016) recommendations regarding funding for regional education. The government anticipates that further to the goals mentioned $\overline{a b o v e}$, the reform will also allow schools to provide higher-quality training for its teaching staff. In terms of teachers' salaries, the new system will also take into account average class repletion and the share of students with special educational needs. 


\section{ANNEX A: STRUCTURE OF THE CZECH REPUBLIC'S EDUCATION SYSTEM}

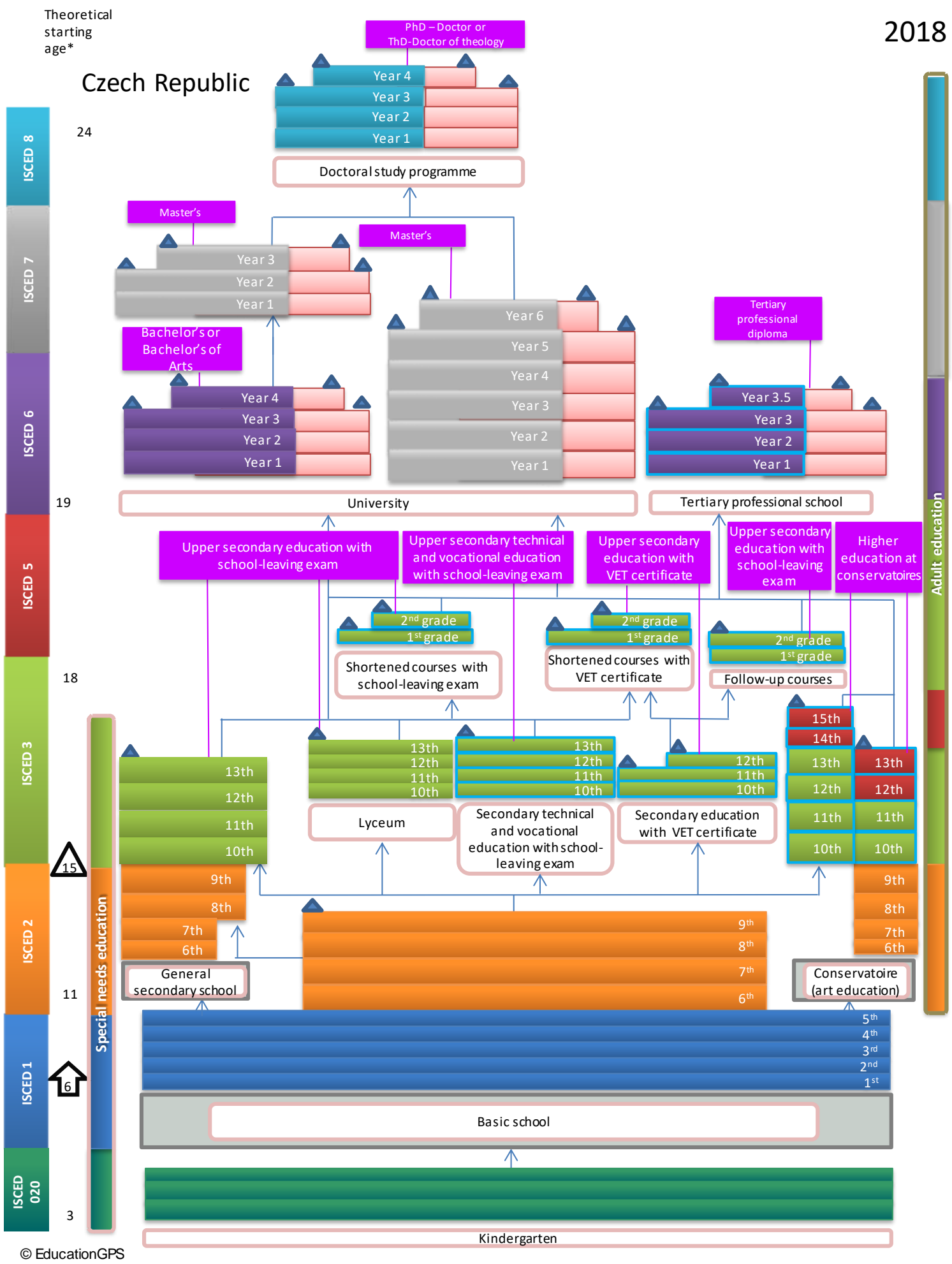

Note: The key for the interpretation of this table is available at the source link below.

Source: OECD (2018), "Czech Republic: Overview of the Education System", OECD Education GPS,

http://gpseducation.oecd.org/Content/MapOfEducationSystem/CZE/CZE 2011 EN.pdf. 


\section{ANNEX B: STATISTICS}

\begin{tabular}{|c|c|c|c|c|c|}
\hline$\#$ & List of key indicators $\mathbf{s}^{1,2,3}$ & $\begin{array}{l}\text { Czech } \\
\text { Republic }\end{array}$ & $\begin{array}{l}\text { Average } \\
\text { or total }\end{array}$ & $\begin{array}{l}\text { Min } \\
\text { OECD }\end{array}$ & $\begin{array}{l}\text { Max } \\
\text { OECD }\end{array}$ \\
\hline \multicolumn{6}{|c|}{ Background information } \\
\hline \multicolumn{6}{|c|}{ Economy } \\
\hline 1 & $\begin{array}{l}\text { GDP per capita, 2016, in equivalent USD converted using PPPS (OECD } \\
\text { Statistics) }\end{array}$ & 35234 & 42441 & 14276 & 107775 \\
\hline 2 & GDP grow th, 2016 (OECD Statistics) & $2.5 \%$ & $1.8 \%$ & $0.6 \%$ & $6.6 \%$ \\
\hline \multicolumn{6}{|c|}{ Society } \\
\hline 3 & Population density, inhab/km², 2017 (OECD Statistics) & 137 & 37 & 3 & 517 \\
\hline 4 & $\begin{array}{l}\text { Population aged less than } 15 \text { as a percentage of total population, } 2018 \\
\text { (OECD Data) }\end{array}$ & $15.8 \%$ & $17.0 \%$ & $12.2 \%$ & $28.4 \%$ \\
\hline 5 & $\begin{array}{l}\text { Foreign-born population as a percentage of total population, } 2018 \text { or } \\
\text { latest available year (OECD Data) }\end{array}$ & $7.5 \%$ & $14.4 \%$ & $0.8 \%$ & $47.6 \%$ \\
\hline \multicolumn{6}{|c|}{$\begin{array}{ll}\text { Education outcomes } \\
\end{array}$} \\
\hline 6 & Mean performance in reading (PISA 2018) & 490 & 487 & 412 & 523 \\
\hline \multirow{4}{*}{7} & \multicolumn{5}{|c|}{ Average three-year trend in performance across PISA assessments, by domain (PISA 2018) 4,5} \\
\hline & Reading performance & 0.1 & 0.4 & -4.9 & 7.1 \\
\hline & Mathematics performance & -3.7 & -0.6 & -9.1 & 6.4 \\
\hline & Science performance & -4.0 & -1.9 & -10.7 & 6.4 \\
\hline 8 & $\begin{array}{l}\text { Enrolment rates of 3-year-olds in early childhood education and care, } \\
2017 \text { (EAG 2019) }\end{array}$ & $79.1 \%$ & $79.3 \%$ & $2.4 \%$ & $100 \%$ \\
\hline 9 & $\begin{array}{l}\text { Percentage of 25-64 year-olds w hose highest level of attainment is } \\
\text { low er secondary education, } 2018 \text { (EAG 2019) }\end{array}$ & $5.9 \%$ & $14.4 \%$ & $0.8 \%$ & $39.9 \%$ \\
\hline \multirow{4}{*}{10} & \multicolumn{5}{|c|}{ Educational attainment of the population aged 25-34 by type of attainment, 2018 or latest available } \\
\hline & At least upper secondary education, 2018 (EAG 2019) & $93.7 \%$ & $85.4 \%$ & $50.1 \%$ & $97.8 \%$ \\
\hline & Tertiary education, 2018 (EAG 2019) & $33.3 \%$ & $44.3 \%$ & $23.4 \%$ & $69.6 \%$ \\
\hline & $\begin{array}{l}\text { Vocational upper-secondary or post-secondary non-tertiary education } \\
\text { (EAG database, } 2017 \text { or latest available year) }\end{array}$ & $\mathrm{m}$ & $24.0 \%$ & $1.9 \%$ & $51.9 \%$ \\
\hline \multirow{4}{*}{11} & \multicolumn{5}{|c|}{ Unemployment rates of 25-34 year-olds by educational attainment, 2018 (EAG 2019) } \\
\hline & Below upper secondary & $12.6 \%$ & $13.7 \%$ & $3.0 \%$ & $37.3 \%$ \\
\hline & Upper secondary and post-secondary non-tertiary & $2.6 \%$ & $7.3 \%$ & $2.5 \%$ & $25.1 \%$ \\
\hline & Tertiary education & $1.7 \%$ & $5.5 \%$ & $1.7 \%$ & $23.2 \%$ \\
\hline \multicolumn{6}{|c|}{ Students: Raising outcomes } \\
\hline \multicolumn{6}{|c|}{ Policy lever 1: Equity and quality } \\
\hline 12 & First age of selection in the education system (PISA 2018) & 11 & 14 & 10 & 16 \\
\hline \multirow{3}{*}{13} & \multicolumn{5}{|c|}{ Students performing at the highest or lowest levels in reading (\%) (PISA 2018) } \\
\hline & Students performing below Level 2 & $20.7 \%$ & $22.6 \%$ & $11.1 \%$ & $49.9 \%$ \\
\hline & Students performing at Level 5 or above & $8.2 \%$ & $8.7 \%$ & $0.8 \%$ & $15.0 \%$ \\
\hline 14 & $\begin{array}{l}\text { Percentage of students in schools where students are grouped by } \\
\text { ability into different classes for all subjects, PISA } 2015\end{array}$ & $3.5 \%$ & $7.8 \%$ & $0.0 \%$ & $56.1 \%$ \\
\hline 15 & $\begin{array}{l}\text { Percentage of students whose parents reported that the schooling } \\
\text { available in their area includes tw o or more other schools, PISA } 2015\end{array}$ & $\mathrm{~m}$ & $36.8 \%$ & $20.4 \%$ & $56.9 \%$ \\
\hline
\end{tabular}




\begin{tabular}{|c|c|c|c|c|c|}
\hline$\#$ & List of key indicators ${ }^{1,2,3}$ & $\begin{array}{c}\text { Czech } \\
\text { Republic }\end{array}$ & $\begin{array}{c}\text { Average } \\
\text { or total }\end{array}$ & $\begin{array}{l}\text { Min } \\
\text { OECD }\end{array}$ & $\begin{array}{l}\text { Max } \\
\text { OECD }\end{array}$ \\
\hline 16 & $\begin{array}{l}\text { Percentage of students reporting that they have repeated at least a } \\
\text { grade in primary, low er secondary or upper secondary schools (PISA } \\
\text { 2015) }\end{array}$ & $4.8 \%$ & $11.3 \%$ & $0.0 \%$ & $42.6 \%$ \\
\hline 17 & $\begin{array}{l}\text { Percentage of variance in reading performance in PISA test explained } \\
\text { by ESCS (PISA 2018) }\end{array}$ & $16.5 \%$ & $12.0 \%$ & $6.2 \%$ & $19.1 \%$ \\
\hline 18 & $\begin{array}{l}\text { Score difference in reading performance in PISA betw een non- } \\
\text { immigrant and immigrant students AFTER adjusting for socio-economic } \\
\text { status (PISA 2018) }\end{array}$ & -34 & -24 & -80 & 16 \\
\hline 19 & Score difference betw een girls and boys in reading (PISA 2018) ${ }^{4}$ & 33 & 30 & 10 & 52 \\
\hline \multicolumn{6}{|c|}{ Policy lever 2: Preparing students for the future } \\
\hline 20 & $\begin{array}{l}\text { Mean proficiency in literacy among adults aged } 16-64 \text { on a scale of } 500 \\
\text { (Survey of Adult Skills, PIAAC, 2012) }\end{array}$ & 274.0 & 267.7 & 220.1 & 296.2 \\
\hline 21 & $\begin{array}{l}\text { Difference in literacy scores betw een younger (25-34) and older (55- } \\
65) \text { adults AFTER accounting for age, gender, education, immigrant and } \\
\text { language background and parents' educational attainment (Survey of } \\
\text { Adult Skills, PIAAC, 2012). }\end{array}$ & 14.3 & 15.6 & -8.3 & 37.6 \\
\hline \multirow{4}{*}{22} & \multicolumn{5}{|l|}{ Share of students in upper secondary education in 2017 following: } \\
\hline & General programmes (OECD Stat - INES 2020) & $27.6 \%$ & $58.1 \%$ & $27.6 \%$ & $100.0 \%$ \\
\hline & Vocational programmes (OECD Stat - INES 2020) & $72.4 \%$ & $43.1 \%$ & $9.0 \%$ & $72.4 \%$ \\
\hline & Combined school and w ork-based programmes (OECD Stat - INES 2020) & a & $18.3 \%$ & $1.0 \%$ & $58.0 \%$ \\
\hline 23 & $\begin{array}{l}\text { First-time graduation rates from tertiary education, } 2017 \text { (Below the age } \\
\text { of } 30 \text {, excluding mobile students / OECD Stat - INES 2020) }\end{array}$ & $27.7 \%$ & $36.6 \%$ & $10.1 \%$ & $49.9 \%$ \\
\hline 24 & $\begin{array}{l}\text { Percentage of 18-24 year-olds not in education, employment or training, } \\
2018 \text { (EAG 2019) }\end{array}$ & $\mathrm{m}$ & $14.3 \%$ & $5.9 \%$ & $29.8 \%$ \\
\hline \multicolumn{6}{|c|}{ Institutions: Im proving schools } \\
\hline \multicolumn{6}{|c|}{ Policy lever 3: School improvement } \\
\hline \multirow{4}{*}{25} & \multicolumn{5}{|l|}{ The Learning Environment - PISA 2018} \\
\hline & Mean index of teacher support in language-of-instruction lessons & -0.22 & 0.01 & -0.61 & 0.47 \\
\hline & Mean index of disciplinary climate & -0.02 & 0.04 & -0.34 & 1.07 \\
\hline & Mean index of students' sense of belonging & -0.28 & 0.00 & -0.28 & 0.46 \\
\hline 26 & $\begin{array}{l}\text { Percentage of teachers in low er secondary education aged } 50 \text { years } \\
\text { old or more, } 2017 \text { (EAG 2019) }\end{array}$ & $36.5 \%$ & $37.0 \%$ & $6.3 \%$ & $54.2 \%$ \\
\hline \multirow{3}{*}{27} & \multicolumn{5}{|c|}{ Number of teaching hours per year in public institutions by education level, 2018 (EAG 2019) ${ }^{7}$} \\
\hline & Primary education & 617 & 783 & 561 & 1063 \\
\hline & Low er secondary education, general programmes & 617 & 709 & 481 & 1063 \\
\hline 28 & $\begin{array}{l}\text { Ratio of actual teachers' salaries to earnings for full-time, full-year adult } \\
\text { w orkers w ith tertiary education, low er secondary education, general } \\
\text { programmes, } 2016 \text { (EAG 2019) }\end{array}$ & 0.64 & 0.88 & 0.64 & 1.40 \\
\hline 29 & $\begin{array}{l}\text { Proportion of teachers w ho believe the teaching profession is valued in } \\
\text { society (TALIS 2018) }\end{array}$ & $16.0 \%$ & $25.8 \%$ & $4.5 \%$ & $67.0 \%$ \\
\hline 30 & $\begin{array}{l}\text { Proportion of teachers who w ould become a teacher again if they could } \\
\text { choose (TALIS 2018) }\end{array}$ & $74.0 \%$ & $75.6 \%$ & $54.9 \%$ & $92.2 \%$ \\
\hline
\end{tabular}




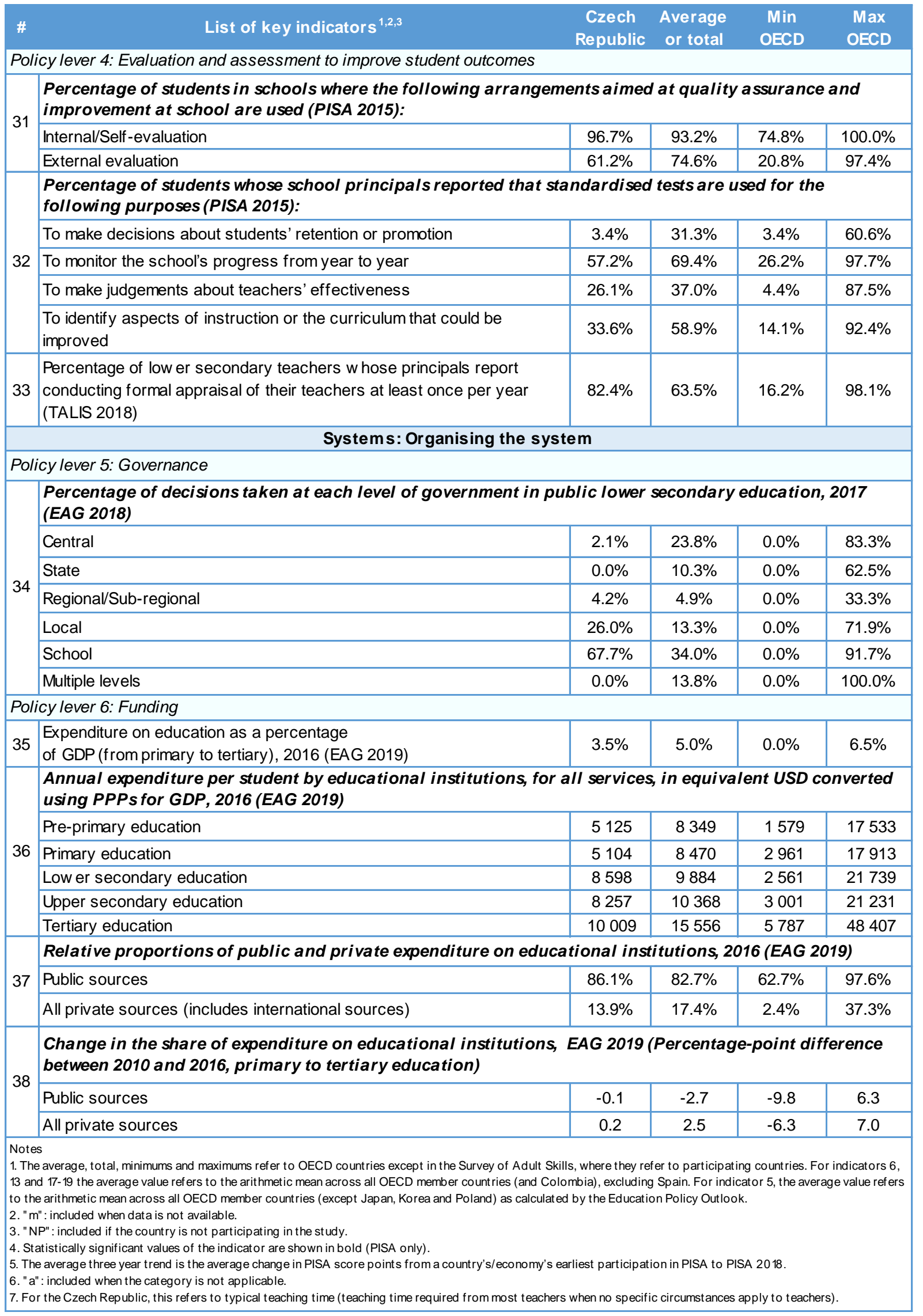




\section{REFERENCES AND FURTHER READING}

Agency for Social Inclusion (n.d.), "Individual project OP RDE - Inclusive and Quality Education in Territories with SVL", Home - About Us, Agency for Social Inclusion, webpage, www.socialni-zaclenovani.cz/individualniprojekt-op-vvv-inkluzivni-a-kvalitni-vzdelavani-v-uzemich-se-svl/ (accessed 08 June 2020).

Araújo, S. and P. Maleček (2015), "Strengthening skill use and school-to-work transitions in the Czech Republic", OECD Economics Department Working Papers, No. 1206, OECD Publishing, Paris, https://doi.org/10.1787/5js1pz2xnm6b-en.

Babiš, A. (2019), Letter from the Prime Minister of the Czech Republic to the Commissioner of Human Rights of the Council of Europe, 11 January 2019, Prime Minister's Office, Prague, https://rm.coe.int/1680908b0b.

Cedefop (2017), "Czech Republic: reform of regional funding", News and Press, Cedefop, webpage, www.cedefop.europa.eu/en/news-and-press/news/czech-republic-reform-regional-education-funding (accessed 08 June 2020).

Centre for Policy Studies of the Central European University (2018), A Synthesis Report on Implementation of National Roma Integration Strategies in Bulgaria, Czech Republic, Hungary, Romania and Slovakia, Publications Office of the European Union, Luxembourg, https://cps.ceu.edu/sites/cps.ceu.edu/files/ attachment/basicpage/3034/rcm-civil-society-monitoring-report-1-synthesis-cluster-1-2017-eprint.pdf.

ČŠI (2020), "What is NIQES?", National System of Inspection Evaluation of Education System, webpage, www.niqes.cz/Co-je-NIQES (accessed 08 June 2020).

ČŠı (2019), "Complex System of Evaluation”, ČŠı, webpage www.csicr.cz/Prave-menu/Projekty-ESF/Komplexnisystem-hodnoceni (accessed 08 June 2020).

Čšı (2017), Sample Survey of Students' Results at the 5th and 9th Grade of Basic Education 2016/17: Final Report, ČŠI, Prague, https://www.csicr.cz/getattachment/17f8e265-b04f-4459-a1063aecbf735ca0/Vyberove-zjistovani-vysledku-zaku-na-urovni-5-a-9-rocniku-ZS-zaverecna-zprava.pdf.

European Agency for Special Needs and Inclusive Education (2019), Country Policy Review and Analysis: Czech Republic, European Agency for Special Needs and Inclusive Education, Odense, https://www.europeanagency.org/sites/default/files/cpra czech republic grid.pdf.

European Association for Quality Assurance in Higher Education et al. (2015), Standards and Guidelines for Quality Assurance in the European Higher Education Area (ESG), European Association for Quality Assurance in Higher Education, Brussels, https:/enqa.eu/wp-content/uploads/2015/11/ESG 2015.pdf.

EC (2020), Commission Staff Working Document: Country Report Czech Republic 2020, SWD(2020) 202 final, EC, Brussels, https://ec.europa.eu/info/sites/info/files/2020-european semester country-report-czechrepublic en.pdf.

EC (2020), Council Recommendation on the 2020 National Reform Programme of Czechia and Delivering a Council Opinion on the 2020 Convergence Programme of Czechia, COM(2020) 503 final, EC, Brussels, https://ec.europa.eu/info/sites/info/files/2020-european-semester-csr-comm-recommendationczechia en.pdf.

EC (2019), Education and Training Monitor 2019: Czech Republic, Publications Office of the European Union, Luxembourg, https://ec.europa.eu/education/sites/education/files/document-library-docs/et-monitor-report2019-czech-republic en.pdf.

EC (2019), Commission Staff Working Document: Country Report Czech Republic 2019, SWD(2019) 202 final, EC, Brussels, https://ec.europa.eu/info/sites/info/files/file import/2019-european-semester-country-reportczech-republic en.pdf.

EC (2019), National Student Fee and Support Systems in European Higher Education 2018/19, Eurydice Facts and Figures, Publications Office of the European Union, Luxembourg, https://eacea.ec.europa.eu/nationalpolicies/eurydice/sites/eurydice/files/fee support 201819 report en.pdf.

EC (2018), Education and Training Monitor 2018: Czech Republic, Publications Office of the European Union, Luxembourg https://ec.europa.eu/education/sites/education/files/document-library-docs/et-monitor-report2018-czech-republic en.pdf. 
28 | No. 11 - EDUCATION POLICY OUTLOOK IN THE CZECH REPUBLIC

EC (2018), Commission Staff Working Document: Country Report Czech Republic 2018, SWD(2018) 202 final, Brussels, https://ec.europa.eu/info/sites/info/files/2018-european-semester-country-report-czech-republicen.pdf.

EC (2017), Education and Training Monitor 2017: Czech Republic, Publications Office of the European Union, Luxembourg, https://ec.europa.eu/education/sites/education/files/monitor2017-cz en.pdf.

EC (2016), Education and Training Monitor 2016: Czech Republic, Publications Office of the European Union, Luxembourg, https://ec.europa.eu/education/sites/education/files/monitor2016-cz en.pdf.

EC (2010), Europe 2020: A European Strategy for Smart, Sustainable and Inclusive Growth, EC, Brussels, https://eur-lex.europa.eu/legal-content/EN/TXT/PDF/?uri=CELEX:52010DC2020\&from=en.

EC/EACEA/Eurydice (2020), "Ongoing Reforms and Policy Developments", Eurydice - Czech Republic, Eurydice, webpage, https://eacea.ec.europa.eu/national-policies/eurydice/content/ongoing-reforms-and-policydevelopments-17 en (accessed 08 June 2020).

European Trade Union Committee for Education (2017), "Czech Republic: the End of Cheap Teachers", HomeNews, 11 January 2017, European Trade Union Committee for Education, webpage, www.cseeetuce.org/en/news/archive/1806-czech-republic-the-end-of-cheap-teachers (accessed 08 June 2020).

European Union Agency for Fundamental Rights (2018), A Persisting Concern: Anti-Gypsyism as a Barrier to Roma Inclusion, Publications Office of the European Union, Luxembourg https://fra.europa.eu/sites /default/files/fra uploads/fra-2018-anti-gypsyism-barrier-roma-inclusion en.pdf.

Eurostat (2020), Early Leavers from Education and Training by Sex and Labour Status (indicator), http://appsso.eurostat.ec.europa.eu/nui/show.do?dataset=edat Ifse 14\&lang=en (accessed 08 June 2020).

Government of the Czech Republic (2019), Decree Amending Decree No. 27/2016 On Education of Pupils with Special Educational Needs and Gifted Pupils as Amended, Decree No. 248/2019, Government of the Czech Republic, Prague, https://www.zakonyprolidi.cz/cs/2019-248.

Government of the Czech Republic (2019), Education Act (2004) as Amended from 15 February 2019, Government of the Czech Republic, Prague, http://www.msmt.cz/dokumenty-3/skolsky-zakon-ve-zneniucinnem-od-15-2-2019.

Government of the Czech Republic (2017), Higher Education Act (1998) as Amended from 6 September 2017, Government of the Czech Republic, Prague, http://www.msmt.cz/areas-of-work/tertiary-education/thehigher-education-act?lang=2.

Government of the Czech Republic (2017), Education Act (2004) as Amended from 05 April 2017, Government of the Czech Republic, Prague, https://www.zakonyprolidi.cz/cs/2017-101.

Government of the Czech Republic (2015), Education Act (2004) as Amended from 17 April 2015, Government of the Czech Republic, Prague, https://www.zakonyprolidi.cz/cs/2015-82.

Government of the Czech Republic (2014) Strategy for Education Policy of the Czech Republic until 2020, Government of the Czech Republic, Prague, http://www.vzdelavani2020.cz/images obsah/dokumenty Istrategy web en.pdf.

Kaňáková, M., V. Czesaná and Z Šímová (2019), Vocational Education and Training in Europe - Czech Republic, Cedefop ReferNet - VET in Europe reports, Thessaloniki, https://cumulus.cedefop.europa.eu /files/vetelib/2019/Vocational Education Training Europe Czech Republic 2018 Cedefop ReferNet.pdf.

Kaščák, O. et al. (2019), Progress Evaluation of the Implementation Strategy of the Educational Policy of the Czech Republic in 2020, MŠMT, Prague, http://www.vzdelavani2020.cz/images obsah/dokumenty/ hodnoceni-naplnovani-strategie-vzdelavaci-politiky-cr-do-roku-20020/strategie2020 zprava.pdf.

Kuczera, M. (2010), OECD Reviews of Vocational Education and Training: A Learning for Jobs Review of the Czech Republic 2010, OECD Reviews of Vocational Education and Training, OECD Publishing, Paris, https://doi.org/10.1787/9789264113756-en.

Messing, V. (2017), "Differentiation in the Making: Consequences of School Segregation of Roma in the Czech Republic, Hungary, and Slovakia", European Education, Vol. 49/1, pp. 89-103, https://www.tandfonline.com/doi/pdf/10.1080/10564934.2017.1280336?needAccess=true.

Mijatović, D. (2018), Letter from the Commissioner for Human Rights of the Council of Europe to the Prime Minister and Minister of Education, Youth and Sports of the Czech Republic, 19 December 2018, 


\section{9 | No. 11 - EDUCATION POLICY OUTLOOK IN THE CZECH REPUBLIC}

Strasbourg, https://rm.coe.int/letter-to-andrej-babis-prime-minister-and-robert-plaga-minister-ofedu/1680907a6c.

MPSV (n.d.), "What is the National System of Occupations?", Home - What is the NSP?, MPSV, webpage, www.nsp.cz/info/co-je-nsp (accessed 08 June 2020).

MŠMT (2020), "National Register of Qualifications", Home - Qualifications, MŠMT, Prague, webpage, www.narodnikvalifikace.cz/en-us/ (accessed 08 June 2020).

MŠMT (2019), Long-term plan for Education and the Development of the Education System of the Czech Republic 2019-2023, MŠMT, Prague, http://www.msmt.cz/vzdelavani/skolstvi-v-cr/dz-cr-2019-2023.

MŠMT (2018), Interim Evaluation of the Implementation of the Digital Education Strategy up to 2020 (2018), MŠMT, Prague, http://www.msmt.cz/file/50081 1 1/.

MŠMT (2017), Development Program: Increase in Salaries of Teaching Staff and non-Teaching Staff Employees of Regional School, MŠMT, Prague, http://www.msmt.cz/uploads/odbor 12/28805/Vyhlaseni rozvojoveho programu.pdf.

MŠMT (2017), "The VVV Operational Programme has already supported over 3800 projects worth more than 20 billion”, Press Releases, MŠMT, webpage, http://www.msmt.cz/ministerstvo/novinar/operacni-programvyzkum-vyvoj-a-vzdelavani-podporil-jiz-pres?lang=1 (accessed 08 June 2020).

MŠMT (2015), Methodological Recommendation to Ensure a Uniform Procedure for Concluding a Contract on the Content, Scope and Conditions of Practical Training, MŠMT, Prague, www.msmt.cz/uploads/021/O211/smlouva skola firma/doporuceni k jednotnemu postupu .pdf.

MŠMT (2015), Long-term plan for Education and the Development of the Education System of the Czech Republic (2015-2020), MŠMT, Prague, www.msmt.cz/vzdelavani/skolstvi-v-cr/dlouhodoby-zamer-vzdelavani-arozvoje-vzdelavaci-soustavy-3.

MŠMT (2014), Digital Strategy for Education, MŠMT, Prague, www.msmt.cz/uploads/DigiStrategie.pdf.

NIDV (2020), Strategic Management and Planning in Schools and Territories, NIDV, Prague, http://projekty.nidv.cz/strategicke-rizeni.

NÚV (n.d.), "Revision of the Framework Educational Programme", NÚV, webpage, www.nuv.cz/t/rrvp (accessed 08 June 2020).

NÚV (n.d.), "Support for Capacity Building for the Development of Basic Literacy in Pre-primary and Primary Education - Support for Teacher Work", NÚV, webpage, www.nuv.cz/projekty/ppuc?lang=1 (accessed 08 June 2020).

NúV (n.d.), "Background Analytical Studies", NúV, webpage, www.nuv.cz/t/rrvp/04 (accessed 08 June 2020).

NúV (2015), National Referencing Report of the Czech Republic, Publications Office of the European Union, Luxembourg, https://ec.europa.eu/ploteus/sites/eacegf/files/national referencing report czech republic 2015 eng.pdf.

OECD (2020), TALIS 2018 Results (Volume II): Teachers and School Leaders as Valued Professionals, TALIS, OECD Publishing, Paris, https://doi.org/10.1787/19cf08df-en.

OECD (2020), PISA 2018 Results (Volume III): What School Life Means for Students' Lives, PISA, OECD Publishing, Paris, https://doi.org/10.1787/acd78851-en.

OECD (2020), Foreign-born population (indicator), doi: 10.1787/5a368e1b-en (accessed 20 April 2020).

OECD (2020), Young population (indicator), doi: 10.1787/3d774f19-en (accessed 14 April 2020).

OECD (2020), Learning Remotely when Schools Close: How well are Students and Schools Prepared? Insights from PISA, OECD Policy Responses to Coronavirus (COVID-19), OECD Publishing, Paris, https://read.oecd-ilibrary.org/view/?ref=127 127063-iiwm328658\&title=Learning-remotely-when-schoolsclose.

OECD (2019), Education Policy Outlook 2019: Working Together to Help Students Achieve their Potential, OECD Publishing, Paris, https://doi.org/10.1787/2b8ad56e-en.

OECD (2019), PISA 2018 Results (Volume II): Where All Students Can Succeed, PISA, OECD Publishing, Paris, https://doi.org/10.1787/b5fd1b8f-en. 
30 | No. 11 - EDUCATION POLICY OUTLOOK IN THE CZECH REPUBLIC

OECD (2019), PISA 2018 Results (Volume I): What Students Know and Can Do, PISA, OECD Publishing, Paris, https://doi.org/10.1787/5f07c754-en.

OECD (2019), TALIS 2018 Results (Volume I): Teachers and School Leaders as Lifelong Learners, TALIS, OECD Publishing, Paris, https://doi.org/10.1787/1d0bc92a-en.

OECD (2019), Education at a Glance 2019: OECD Indicators, OECD Publishing, Paris, https://doi.org/10.1787/f8d7880d-en.

OECD (2018), Education at a Glance 2018: OECD Indicators, OECD Publishing, Paris, https://doi.org/10.1787/eag-2018-en.

OECD (2018), OECD Economic Surveys: Czech Republic 2018, OECD Publishing, Paris, https://doi.org/10.1787/eco surveys-cze-2018-en.

OECD (2018), The Resilience of Students with an Immigrant Background: Factors that Shape Well-being, OECD Reviews of Migrant Education, OECD Publishing, Paris, https://doi.org/10.1787/9789264292093-en.

OECD (2017), Starting Strong 2017: Key OECD Indicators on Early Childhood Education and Care, Starting Strong, OECD Publishing, Paris, https://doi.org/10.1787/9789264276116-en.

OECD (2016), OECD Economic Surveys: Czech Republic 2016, OECD Publishing, Paris, https://doi.org/10.1787/eco surveys-cze-2016-en.

OECD (2014), OECD Economic Surveys: Czech Republic 2014, OECD Publishing, Paris, https://doi.org/10.1787/eco surveys-cze-2014-en.

OECD (2011), OECD Economic Surveys: Czech Republic 2011, OECD Publishing, Paris, https://doi.org/10.1787/eco surveys-cze-2011-en.

Ombudmsan of the Czech Republic (2017), Ombudsman's Recommendations on the Joint Education of Roma and non-Roma Children, Office of the Public Defender of Rights, Brno, https://ochrance.cz/fileadmin/ user upload/ESO/86-2017-DIS-VB Doporuceni desegregace.pdf.

Redecker, C. (2017), European Framework for the Digital Competence of Educators, JRC Science for Policy Report, Publications Office of the European Union, Luxembourg, http://publications.jrc.ec.europa.eu/ repository/bitstream/JRC107466/pdf digcomedu a4 final.pdf.

Santiago, P., et al. (2012), OECD Reviews of Evaluation and Assessment in Education: Czech Republic 2012, OECD Reviews of Evaluation and Assessment in Education, OECD Publishing, Paris, https://doi.org/10.1787/9789264116788-en.

Shewbridge, C. et al. (2016), OECD Reviews of School Resources: Czech Republic 2016, OECD Reviews of School Resources, OECD Publishing, Paris, https://dx.doi.org/10.1787/9789264262379-en.

Slovo 21 (2018), Civil Society Monitoring Report on Implementation of the National Roma Integration Strategy in the Czech Republic: Assessing the Progress in four key policy areas of the Strategy, Roma Civil Monitor, Publications Office of the European Union, Luxembourg https://cps.ceu.edu/sites/cps.ceu.edu /files/attachment/basicpage/3034/rcm-civil-society-monitoring-report-2-czech-republic-2018-eprint-fin-2.pdf.

Taguma, M., I. Litjens and K. Makowiecki (2012), Quality Matters in Early Childhood Education and Care: Czech Republic 2012, Quality Matters in Early Childhood Education and Care, OECD Publishing, Paris, https://doi.org/10.1787/9789264176515-en.

Veseley, A. (2019), Preparation of the Broad Educational Policies Czech Republic 2030+: Summary of Previous Work, MŠMT, Prague, https://drive.google.com/file/d/1WI9DEn3RPDU30XH3a6F6z6oYCKvOgwza/view. 
31 No. 11 - EDUCATION POLICY OUTLOOK IN THE CZECH REPUBLIC

\section{NOTES}

1 On 25 May 2018, the OECD Council invited Colombia to become a Member. While Colombia is included in the OECD averages reported in this publication for data from Education at a Glance, the Programme for International Student Assessment and the Teaching and Learning International Survey, at the time of preparation of these OECD datasets, Colombia was in the process of completing its domestic procedures for ratification and the deposit of Colombia's instrument of accession to the OECD Convention was pending.

${ }^{2}$ For the Czech Republic, this refers to typical teaching time (teaching time required from most teachers when no specific circumstances apply to teachers).

${ }^{3}$ For the Czech Republic, this refers to typical teaching time (teaching time required from most teachers when no specific circumstances apply to teachers).

${ }^{4}$ Final funds after transfers between levels of government. 
This paper is published under the responsibility of the Secretary-General of the OECD. The opinions expressed and arguments employed herein do not necessarily reflect the official views of OECD member countries or the European Union.

This document and any map included herein are without prejudice to the status of or sovereignty over any territory, to the delimitation of international frontiers and boundaries and to the name of any territory, city or area.

Photo credits: Cover () Shutterstock/Sasha Chebotarev

(C) OECD 2020

The use of this work, whether digital or print, is governed by the Terms and Conditions to be found at: http://www.oecd.org/termsandconditions. 
This document has also been published as:

OECD (2020), Education Policy Outlook: Czech Republic, available at: www.oecd.org/education/policy-outlook/country-profile-Czech-Republic-2020.pdf.

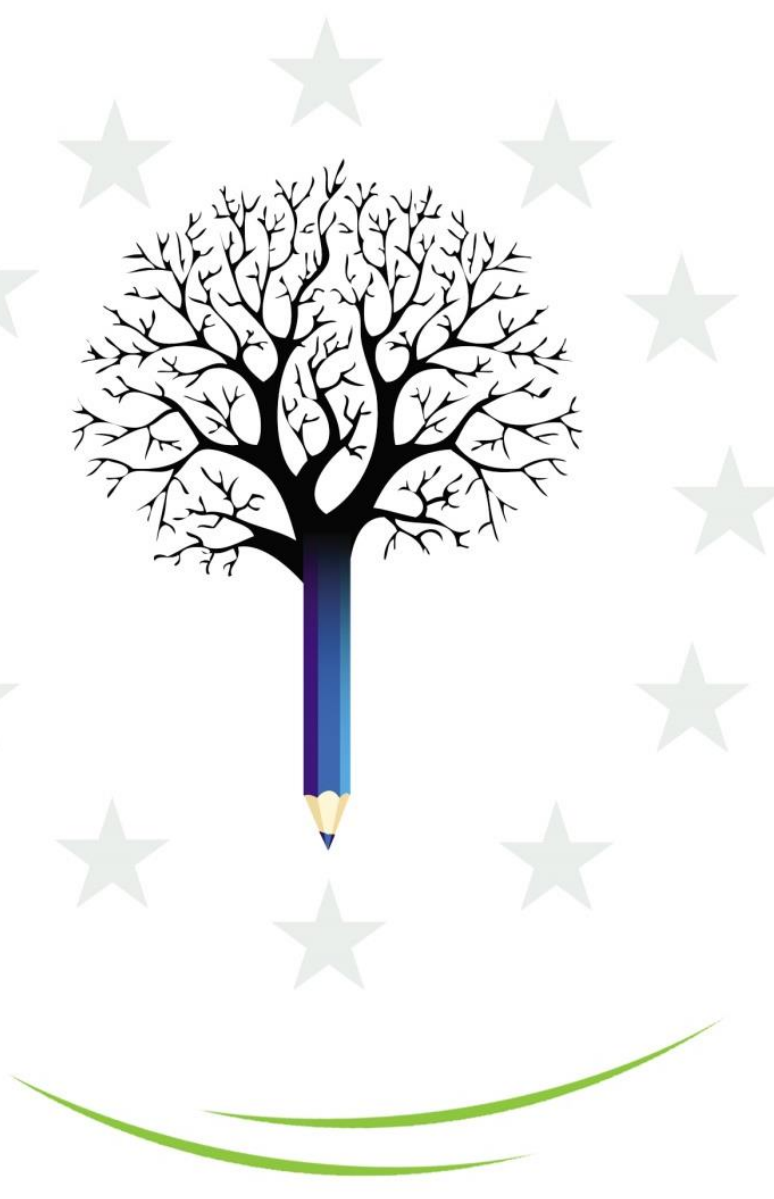

www.oecd.org/edu/policyoutlook.htm 